\title{
O princípio do Direito, de acôrdo com a concepção teleológica
}

\author{
Cadeira: Filosofia do Direito \\ Professor: Dr. João Arruda \\ Aluno: Ernesto Mendonça de Carvalho Borges
}

\begin{abstract}
SUMARIO
1. O velho dissidio -2 . A conciliação -3 . Partidários e antagonistas da concepção teleológica -4 . 0 argumento mais forte dos adversários - 5. Refutação á concepção mecanicista -6 . 0 insucesso da explicação teleológica -7 . A visibilidade dos fins -8 . 0 regresso á metafisica - 9. A finalidade da ação humana - 10 . O dado psicológico - 11. O freudismo - 12. O livre arbitrio e o determinismo - 13. A finalidade do homem - 14. O Bem Supremo - 15. O problema da Dívindade não é alheio á filosofia juridica - 16. A conduta humana -17 . O homem, animal sociaviel -18 . 0 racionalismo -19 . O historicismo -20 . O sociologismo - 21. A razão e o empirismo - 22. A filosofia juridica com saudades da metafisica - 23. A Iei natural - 24. As pretensões da teoria teleológica - 25. 0 motor do progresso moral do homem - 26. O bem comum e o bem particular do homem - 27. Rudolf von Ihering e São Tomaz de Aquino -28 . Conclusão.
\end{abstract}

Ao encerrarmos o presente ano letivo, deveriamos resumir os resultados do que nos ficou do muito que nos foi ensinado, para que pudessemos demonstrar que a bôa semente, lançada a mancheias do alto da ilustrada Cátedra, não caiu - na expressão dos Evangelhos - sôbre pedras.

Eis a razão da escolha de uma tese tão debatida, desde a antiguidade grega: $-a$ finalidade. 
Ela faculta-nos a possibilidade de lançar um golpe de vista sôbre todo o vasto território do Direito, dos cimos da Filosofia, onde a vertigem das alturas talvez não nos permita uma atitude crítica, como era de mister.

Ao demais, os nossos pendores pessoais podem levar-nos a conclusões precipitadas sôbre o magno assunto, que serve de tema a esta dissertação.

As deficiências notadas, certamente, ficarão compensadas com os grandes saldos de sinceridade, com que iremos. abordar a tese sempre controvertida, mas nunca abandonada.

1 - Podemos filiar a concepção da teoria da finalidade, com toda segurança, á filosofia helênica.

Nela encontramos Heráclito em luta com Parmenides.

O grande jonio sustentava, que a "realidade" não passava de uma aparencia efêmera, porque tudo, no Universo, de continuo se transfórma, sob a "lei do melhor" (1).

O “real" será “o que é, apenas; ou, nele, está o que passa a ser, "o que não é": aquilo em que "o que é" se transforma?

O famoso representante da escola eleática contrapõe a idéia do "real", como elemento estavel, permanente, uno e sempre idêntico. (2). Daí a antítese, que constituiu, constitúe e constituirá a preocupação do pensamento humano. (3).

2 - Aristóteles, mais tarde, viu, num relampejo de gênio, o que havia de verdade numa e noutra teoria, e assentou a sua construção eterna do "ato" e "potencia".

Para êle, as transformações incessantes - de que falava Heráclito - não excluem a realidade: - o "não ser" de alguma fórma existe, no "ser" ainda indeterminado, em virtude de sua capacidade real de perfeição. Igualmente, 
o "ser" - de acôrdo com o pensamento de Parmenides existe realmente; contudo, pode transformar-se por essa capacidade especifica, que lhe é peculiar: a "potencia".

A matéria, recebendo, como recebe, muitas determinações, não passa, porisso, a ser a perfeição recebida ou, ainda, o ato recebido; mas ela apenas o limita.

Cada "ser" particular, submetido á mudança, capta um elemento de possibilidade em relação ao que êle não è no presente e ao que êle poderá ser mais tarde. Então, o "não ser" - de Heráclito - já pode ser compreendido, posto em confronto do "ser", cuja existência real foi sustentada pelo mais profundo dos filosofos presocráticos: PARMENides (4).

Si todo "ser" sensivel é composto de "potencia" e "ato"; si o "ato" determina a "potencia", especificando-a; e si a "potencia" limita o "ato", que recebe, e do qual participa de certo modo, - então, há lugar para a compreensão, ainda que relativa, do "não ser" - pela existência de um "ser" determinado em face da determinação ulterior.

Conseqüentemente, não se poderá admitir um realismo absoluto; e o grande valor da obra de Aristóteles está em tê-lo compreendido, admitindo um realismo comedido, que, de um lado, domina os excessos de cada um dos contendores, fugindo, de outro, ao puro "nominalismo": words, words.

Do "ser", em “ato", nada poderia provir realmente, porque êle já se encontrava determinado, - o que não acontecerá em relação ao "ser" em "potencia", ainda indeterminado.

Finalmente, nada poderá ser reduzido da "potencia" ao “ato" senão por um outro "ser" existente, já em "ato", que se denomina "agente", e que atua numa relação de "causa" a "efeito", de acôrdo com uma ordenação, que lhe é peculiar.

De fato, se não existisse essa ordenação, não haveria razão alguma justificativa da ação do "agente", como de sua inação. 
Ele não se acha em estado de indiferença.

D'aí, chegaremos lógicamente á conclusão irreprimivel: - a "potencia" passiva ou ativa está cada uma ordenada ao "ato" como ao seu "fim"

O movimento incessante por que as cousas passam (le devenir), num fluxo constante, explica-se, assim, em função do "ser inteligível", pela dicotomia do "ser" em "potencia" e "ato", e tambem pelas cruatro causas, indicadas pelo genial Estagirita - de que falaremos mais tarde.

3 - A "finalidade" tem sido aceita por alguns filosofos e sábios (Platão, Aristoteles, Sócrates, Newton, Leibnitz, Kant, Cuvier, Bernard, Alberto o Grande, São Thomaz, etc.), e, tambem, impugnada por outros (Demócrito, Epícuro, Lucrécio, Buffon, laplace, Spinoza, Comte, Littré, Spencer, BüchNer, etc.), sendo uma teoria indiferente a outros (Descartes, Bacon, etc.), que se socorreram, de preferência, da explicação mecanicista do Universo.

4 - $\mathrm{O}$ argumento mais forte de seus adversários consiste am que o "fim" não poderá ser "causa", porque esta deverá necessariamente anteceder ao "efeito"

Esquecem eles, porém, que, estando o "fim" na ordem lógica do conhecimento, é anterior á "operação", porque determina a "causa eficiente" a operar, e não poderia determiná-la si não fosse conhecida; mas, na ordem ontológica ou da realidade, ele é posterior á "operação", porque, só por meio da operação, a causa eficiente o atinge".

Uim exemplo disso temos presenciado, muita vez, sob a abóbada verde das matas, onde as pequenas arvores fazem os maiores esforços para alcançar os raios solares indispensaveis á sua existência.

Temos, aí, o "fim" representando o papel de causa, ou melhor, a "causa final" é erigida á categoria de motor da "causa eficiente"

Já ARIstóteles advertia: "causae ad invicem sunt causae, sed in diverso genere" (5 e 6).

5 - Fica, dessarte, explicado, o critério da "causalidade" - que físicos e metafísicos não contestam. O empi- 
rismo apenas constata a conexão entre a "causa" 0 o "efeito", mas nada mais, porque a experiência é incapaz de demonstrar a razão pela qual a "causa" de uma categoria só produz determinado "efeito", numa ordem preestabelecida. Isso sob o ponto de vista filosófico não tem o alcance, que se lhe quer dar, porque, desde agora, sabemos que os fenômenos futuros deverão estar sujeitos á causa racional - o que não deixa de ser um argumento a priori, tão combatido pelos mesmos empiristas.

Demais, a "causalidade" não poderá satisfazer á inteligência humana, porque não nos dá a "origem" e nem o "fim" das cousas.

Se explicasse o ponto de partida, entraria em contradição consigo mesma pelo princípio: "ex nihilo nihil fit". - da sabedoria grega!

Não contestamos a legitimidade do princípio da explicação do Universo per causas, de vez que não desconhecemos os benefícios que êle tem trazido á ciência; impugnamos, tão só, que seja a única explicação admissivel, com exclusão de qualquer outra.

JoRGe DEL Vecchio iluminou, com seu talento, de tal modo êsse assunto, que nada mais nos cumpre fazer do que citar a existência de seus fortes argumentos. (7).

6 - $\mathrm{O}$ insucesso da teoria teleológica não está propriamente na falta de constatação da sua procedência, mas no exagêro de seus partidarios. (8).

7 - Nem sempre os "fins" são visiveis ao espírito; antes êles se perdem na natureza íntima das cousas. Reconhecemos ou estamos aptos a reconhecer a sua existência pela constatação de uma ordem na sucessão fenomênica, de uma direção segura na série causal.

Não é uma visão subjetiva, pois; ao revês, é uma compreensão realista, que, além do mais, corresponde a uma necessidade lógica de nosso espírito, da mesma fórma como quando procuramos um termo inicial para o princípio da causalidade, que, na sua pregressão, não poderá ir ao infinito! 
8 - Estamos em pleno terreno da metafísica, é certo; mas quem desdenhará, hoje, o valor da "filosofia primeira", si, sem ela, sentimos um vasio em nossa inteligência?

Nos tempos modernos já ninguem aceita a "lei dos três estados" (9 e 10).

Volta a metafísica, sob o pálio da Filosofia, a tratar dos princípios mais universais, as mais altas generalidades, que todas as outras ciências supõem, sem que estas possam delas tratar ex professo, por ser muito restrito o seu objeto particular.

Aristóteles volta a reinar (11), tendo caído fragorosamente a tentativa positivista de desinteressar a Filosofia das causas primeiras ou finais - como pretendeu Augusto Comte (12).

A Filosofia Positiva, de "filosofia" só possuia o rótulo, como demonstrou Herbert Spencer (13).

A-pezar-de incluido a contragosto (14) no ról dos positivistas, SPEncer aceitava a concepção do "absoluto" (15), ainda que sob uma representação indefinida (16), bem como de uma "lei universal" admitindo mesmo as intuições fundamentais e essenciais á operação do pensamento (17), a que a Filosofia se vê forçada a recorrer para organizar o seu sistema (18).

E de fato, para dirimir êsse eterno dissídio, nada obsta a que a inteligência humana procure sondar o fundo das cousas, segurando o fio de Ariadne do mistério universal, que a "finalidade", como vimos, tenta prender (19).

9 - Sôbre a existência de um evidente elemento teleológico como motor das ações humanas já cessa o dissídio.

Um exame introspectivo, a-pezar-de toda a sua subjetividade, é mais do que suficiente, mesmo para os que não considerem o conhecimento de sua própria personalidade como o último grau de conhecimento, o mais requintado, e, por sua natureza, superior á orientação objetiva do pensamento, porque, por êle, é que o homem se identifica: "Gogito, ergo sum" - como afirmara Descartes. 
Maravilhosa é essa identificação de sua própria personalidade, de seu "ser", a-pezar-das mutações sofridas sob a ação de finalidades várias e de sua potencialidade para novas transformações, no incessante fluxo universal.

10 - 0 Homem possúe, assim, um quid, que a ciência psicológica jamais poderá devassar, e que, por isso, já fôra elevada á categoria de um epifenômeno, máu grado as investidas freqüentes da psicologia experimental em reduzir a "conciência" a um "material" de laboratorio (20).

Julio LACHElier já advertia, a-pezar-de ser considerado como uma "fria inteligência, extranha aos movimentos da imaginação e da sensibilidade", que os fenômenos psicológicos não podem ser inteligiveis e reais (21), declarando, categóricamente, que a psicologia não poderá acabar senão na metafísica, - tentando assim conter o movimento iniciado em seu tempo de levar as raias daquela ciência até á fisiologia.

Se, de fato, a realidade, quanto ao mundo físico, não pode ser captada pelas antenas possantes da ciência, então, com maior razão, como pode esta tentar, dentro dos limites do verdadeiro, ferir a "realidade psicológica", envolta no mais tenebroso mistério?

11 - A tentativa atrevida de Freud de conter a atividade bio-psíquica do homem dentro da fórmula da "libido" não passa de mais uma manifestação de "romantismo", ou, antes, de "misticismo" científico, oriundo de uma visão unilateral de problema infinitamente poliédrico, - tal como aconteceu, na esfera da ciência jurídica, com a hipótese central do "materialismo histórico".

O Dr. Franco da Rocha, um dos maiores divulgadores da psicanálise, abre o seu livro sôbre esta doutrina com as seguintes palavras:

"A doutrina de Freud constitúe um sistema de medicina especial das nevroses e psicoses" (22)

Assim compreendida, como teoria científica, nada temos a contestar, porque, nesse terreno, dirão a última palavra a 
própria ciência e os seus sábios, e sabemos que a sua opinião ẻ desfavoravel ao freudismo.

Desde, porém, como já se tem tentado, o problema é levado, com todas as suas últimas conseqüencias, para o terreno filosófico, então deveremos combater as conclusões apressadas, induzidas do empirismo; e, para isso, nada mais é preciso do que mostrar qual seja o "valor real" da ciência.

Deveremos dizer ao cientista: "ne sutor ultra crepidam"

A crítica do "valor" da ciência foi feita magistralmente por Henri Ponncaré e por Mach, e, últimamente, por Meyersen, - o que nos dispensará, por certo, de renová-la, para não ampliarmos os limites naturais desta dissertação. (23).

12 - Abandonando, mesmo, a análise introspectiva, para descermos ao terreno da informação objetiva dos atos humanos - considerado como o método verdadeiramente científico da psicologia, - - ainda assim a "finalidade" explende, repudiando a concepção mecanicista da vontade.

O próprio professor Pedro Lessa, partidário dos mais decididos do determinismo, já acentuava:

“Tanto os adeptos do livre arbítrio, como os sectários do determinismo estão concordes em que o mecanismo da vontade difere do das causas materiais ou do mundo físico" (24).

Observemos, desde já, com a merecida atenção, que a "fatalidade", que alguns materialistas concebem como chave do mistério do Universo, jamais foi aceita como limite da vontade humana.

Os "livre-arbitristas", como os "deterministas" já largaram, em sua grande maioria, as posições extremas, em que se haviam de início colocado.

A vontade humana tem um carateristico, que poucos lhe notaram: ela é inevitável, estando aderida indissociavelmente á nossa personalidade, como a expressão da realidade do "ser" 
Enquanto o homem vive e, portanto, pode exteriorisá-la, êle não cessa de querer, a tal ponto que, mesmo não desejando exercer essa atividade de seu espírito, não poderá impedir o trabalho de sua vontade: “quer não querer!".

E o Direito reconhece o "valor positivo" das omissões.

A vontade, sob êsse aspecto, seria misteriosa, se não corresse em nosso auxílio a interpretação da "finalidade" humana.

Outro aspecto interessante da vontade é a necessidade, am que ela se encontra, de procurar-se uma "justificação"

Já vimos, que o homem sempre quer; mas, nem por isso, o seu "querer" deixa de ter uma razão, um "porque" .

Em todo processo volitivo, iremos demonstrá-lo, há sempre uma justificativa, mesmo entre as suas mais várias cambiantes, mercê das tendências pessoais, das paixões, dos caprichos, das necessidades físicas ou morais, e, !mesmo, dos desejos mais indefinidos e quasi instintivos.

E' fato, que nem sempre a vontade é justificada por um longo arrazoado, pois, em certos casos, uma justificativa rapida é suficiente.

Por exemplo, quando um indivíduo escorrega em um piso encerado, como em um salão de baile, certamente não terá a pretensão de demonstrar, em momento tão dificil quão cớmico, que não cairia si o seu centro de gravidade estivesse dentro de sua base, ou, ainda, não tentará fazer uma dissertação sôbre a necessidade da ginástica para, com agilidade, evitar as quédas. Ele tratará apenas de equilibrar-se o mais depressa possivel, podendo, em seguida, quando muito, depois de realizado o esfôrço para manter-se de pé, afirmar que assim é que todos, em tal emergência, deveriam fazer.

A justificação da vontade, como ela propria, é um fato real, e dela só escapam os dementados e os ébrios.

O livre-arbítrio funda-se nela, não necessitando - para gáudio dos materialistas - recorrer á essência imaterial da alma. 
0 argumento espiritualista, a priori, assim, superabundaria, se, de acôrdo com o empirismo, pudessemos, pela indução, atingir a um princípio universal, que é, de fato, o da justificação da vontade.

Foi o que tentamos fazer, para evitar incidir no conceito de Emmanuel Kant, que - como é sabido - funda a liberdade fóra do tempo, e sem ligação de termo a termo com o tempo, deduzindo daí, lógicamente, que, no ato da escolha, o julgamento prático é absolutamente incondicionado na sua ordem. Para êle, o determinismo fenomenal corre de seu lado, e, de outro, a razão determina-se e, determinando-se, determina o proprio determinismo, contudo, em blóco, em seu caráter total, sem que nisso possa intervir reação da "natureza interior" do homem sôbre a porção de "eternidade", que envolve totalmente seu ser.

Sertillanges - de quem recebemos essa lição (25) conclúe :

"A seguir se vê a conseqüência. Em todos os nossos atos deliberados, a responsabilidade da razão é total; por conseqüência sempre igual a si mesma. Nada de circunstâncias atenuantes, pois que, nessa teoria, é a própria razão que serve de explicação ás circunstâncias"

S. Tomaz admite a contigência na Natureza, da qual o homem participa, considerado, pelo seu corpo, como animal.

Como êste assunto não é tratado senão incidentemente nesta dissertação, iremos resumir o que a respeito informa o citado monografista e ilustre filósofo:

"Em resumo, no sistema tomista, três influências concorrem a explicar o livre arbitrio; mas nenhuma o oprime. Nem a matéria, que intervem na preparação de nossos atos, impõe o resultado; nem a idéia, que os regula, lhes imprime a sua determinação última; nem o transcendente, que em tudo está pressuposto, presente em tudo e em 
tudo ativo, suprime a contigência, que, ao revés, consagra.

São Tomaz dá satisfação a todas as necessidades que êsses três pontos de vista impõem, e escapa ás dificuldades por êles proposta. $\mathrm{O}$ mistério continua; e não é dado ao homem prescrutar-lhe a profundeza intima" (26).

O determinismo tentaria - caso fosse admitido ofuscar ou aniquilar a subjetividade; e, com isso, faria desaparecer todas as condições de uma "realidade moral" - que é o suporte do Direito; ainda que de modo contrário pense Edmond Picard (27).

$\mathrm{E}$ é assim que, hoje, vemos um dos maiores mestres da ciência juridica repudiar o determinismo, que qualifica de ilusão (28), no que é acompanhado por outra grande autoridade (29) — ambos, mirabile dictu, agnosticos!

Paulsen, adversario da teoria teleológica, discriminava os dois campos do pensamento: "tudo deve ser explicado físicamente, e tudo deve ser considerado e interpretado metafísicamente (30).

Se tudo fosse determinado no Universo, qual o espaço para a idéia da liberdade moral e conseqüente responsabilidade jurídica?

Quando, porém, a propalada causalidade das ações humanas provém do íntimo do homem, como uma manifestação de sua própria personalidade, perdendo a natureza de causa efficiens, -- só poderemos explicar, então, a exteriorisação do processo volitivo pelo princípio da finalidade, porque a causa poderá despertar a conciência individual, mas não movê-la para a ação.

13 - A ação humana - em toda sua latitude - é um conjunto de atos internos e externos, e origina-se sob a fórma de apetites, de desejos, de pensamentos, de tendências ou de inclinações, que se identificam com o ser.

Podemos dizer, que a ação, como a vontade, é a vida ou é o próprio homem. 
A ação, pois, deve trazer esteriotipada a tendência de seu autor, mesimo porque a experiencia nos ensina que "não há efeito sem causa"

A dificuldade está, pois, em interpretar-se essa tendência, porque a ação pode visar fins proximos, remotos ou o final do homem, e a direção dêsses fins pode coincidir, iludindo-nos sôbre a extensão querida pelo agente.

Se, porém, considerarmos o Homem, em geral, pelos seus elementos componentes mas integrados em uma só natureza, - concluiremos que, extraindo uma média de todas as suas ações, nos será facil lobrigar uma tendência única, que passa pelas causas próximas e segue adiante para uma finalidade suprema.

$\mathrm{E}^{\prime}$ isso que um autêntico positivista o diz implícitamente, Durkheim :

"Temos necessidade de saber para onde vamos ou, ao menos, de saber que vamos para alguma parte" (31). " $E$ ' necessário que, não somente de tempos a tempos, mas a cada instante de sua vida, possa inteirar-se de que o que faz vai para um fim. Para que sua existencia não lhe pareça vã, é preciso que êle a veja, de uma maneira constante, servir a um fim que the toque imediatamente (32).

Se não soubessemos tratar-se de um positivista, viriamos nessa declaração uma clara alusão ao "fim último" do homem.

Examinemos o nosso "eu", perdido como se acha no seio do Universo, como um átomo de água num oceano infinito; e lembremo-nos de todas as decepções em tudo o que temos buscado como satisfação ao nosso incessante anelo de beatitude.

Nada nos satisfaz inteiramente; todos os prazeres da vida não importam, ainda que reunidos, na repleção psicológica do nosso ser: se não há, dentro de nós, uma sensação de vasio, existe algo de lacunoso, de impreenchivel. 
Demais, os bens materiais são transitórios, caducos como as cousas humanas o são.

Uma voz secreta sussurra ao nosso espírito, confiando-nos o sigilo de que somos feitos para o universal, o eterno!

E é porisso, certamente, que a Humanidade, no curso dos seculos, caminha para um progresso moral - seguindo uma finalidade.

Qual será, porém, o “bem" apetecido pela natureza humana?

Não poderá o homem, pelo esfôrço hercúleo de sua inteligencia, alcançar, ainda que sem clareza, a identificação dêsse "bem", em cujo encalço todas as gerações, em todos os quadrantes da Terra, prosseguem, entre gemidos e dôres?

Dizia Aristóteles que a fonte do movimento está no desejável e no inteligivel (33).

E' porisso, que o engenho humano vai construindo a. Torre de Babel da ciência, que todos os dias, após algumas fragmentações, vai crescendo, em aproximações audaciosas e sucessivas, mas sem tocar jamais o "fim"!

Eis a grande tarefa - quer queiramos, quer não que será dada á Filosofia.

14 - O Bem Supremo, é certo, não tem sido identificado uniformemente, tal como já acentuava PASCAL (34).

A-pesar-de todas as dificuldades, não poderemos manter uma atitude agnóstica, porque, sem êsse conhecimento, a vida humana perde o seu significado, - exclama Cícero (35).

No curso dos tempos, podemos determinar três grandes direções filosoficas sôbre a identificação do Supremo Bem: - a do otimismo grego, a do criticismo kantiano e a do intelectualismo de S. Tomaz.

Entre os mais ilustres representantes do otimismo helênico, Sócrates, Platão, Aristóteles e os Esitoicos, notamos um acôrdo quanto á relação íntima entre a "felicidade", a que todos aspiram, e a "virtude", necessária para alcançá-la.

O Soberano Bem, termo final do espírito humano, surge quasi como uma idéia puramente abstrata. 
Interessa-nos, apenas, extrair das teorias dêsses filósofos o conceito de que a ação humana tem uma finalidade superior, para ficar em perfeita adequação, pela virtude, com o Ser Divino.

Nêle está, pois, a completa felicidade humana.

O genial filósofo de Koennisberg substitúe o imperativo hipotético dos velhos filósofos - "faze isso, si queres aquilo" - pelo "imperativo categórico" - "faze isso" - excluindo o julgamento prático da razão humana, e pondo em seu lugar o que êle chama "julgamento sintético a priori prático", - pela consideração de que a lei da ação moral não está fóra do homem, mas dentro dêle: na sua própria razão.

Afirmar-se que existe um "bem", ao qual se deva conformar a nossa ação, é - para KANT - proferir uma expressão ininteligível, pela razão de que o homem o ignora totalmente.

Com êsse irracionalismo agnóstico, KANT quer salvar apenas a "dignidade humana", ameaçada de imergir no cáos do seculo XVIII -- do qual foi um dos fautores a sua Crítica da Razão Pura.

KANT é paradoxal. (36).

Quando êle resiste á tentação espiritual de ver na virtude o desejo de felicidade, incide no mais desabusado fatalismo, pois a tanto equivale imprimir no ser humano os atributos inalienáveis e intransferíveis do Ser Supremo.

Demais, o "mal moral", em seu sistema, fica inexplicavel, porque o homem - em desacôrdo com as lições da Teodicéa, da Antropologia, da Fisiologia e da Psicologia só age moralmente, quando o faz de conformidade consigo mesmo. Logo - e a conclusão é inelutável - o "mal moral" deveria não existir!

Outra brecha da Crítica da Razão Pura provém de não negar a existencia de fins postos ás ações humanas (37).

Constatamos que êle aceitava a suposição de fins ideais:

" $O$ conceito do bem e do mal não pode ser determinado antes da lei moral, mas somente depois dessa lei e por ela (38). 
"Age de acôrdo com a máxima, em virtude da qual possa cada um propor-se o fim segundo a lei geral" (39).

Este "fim ideal", consistente no perfeito acôrdo da vontade com a lei moral não poderia jamais ser atingido por todos os homens, em virtude do conflito existente entre as inclinações pessoais de cada um e o dever moral, de cunho universal.

Então, KaNT, para cobrir a lacuna, postula a imortalidade da alma, bem como a existencia de Deus, explicativas da realização do Soberano Bem", originando-se da possibilidade da virtude perfeita ou santidade, e pelo acôrdo da felicidade com a virtude. 40).

A nossa impressão pessoal sôbre a Crítica da Razão Prática é de que existe um acentuado pragmatismo nessa parte da obra de Kant, determinante de seu divórcio da Crítica da Razão Pura.

O sábio professor de Koennisberg demonstra não ter certeza na existência das verdades sobrenaturais por êle enunciadas, aceitando-as por julgá-las necessárias á sociedade ou talvez por uma influência de sua formação religiosa. (41).

Chegamos a São Tomaz. Para êste, o Soberano Bem é o fim último da ação humana, tal como já pensavam os filósofos helênicos e, mesmo, Kant...

O Soberano Beim não pode estar nas cousas criadas; é, como já vimos, a experiência que nô-lo indica a cada momento, porque a sua transitoriedade é a negação de que elas possam trazer completa e indestrutivel felicidade ao homem.

A razão, aproveitando-se dos dados da experiência, demonstra que tais cousas, quando muito, podem constituir uma parte dessa felicidade.

o Soberano Bem será o fim da ação humana.

Não o vemos com os nossos olhos, é certo, mas a sua existência explende em todas as maravilhas da Natureza, 
como já nos indicava Santo Agostrnho (42), e mesmo na marcha ascencional da Humanidade, como já explicara Rudolf von Ihering (43).

15 - Poderemos, no terreno filosófico, dizer, como o salmista :

"Vias tuas, Domine, demonstra mihi?

Spencer já elucidava:

"Como a Religião, a Filosofia admite êsse fundo primordial que a conciência implica, o princípio que, como vimos, tem os fundamentos os mais profundos" (44).

Robora Blondel, considerado atualmente o mais profundo filósofo francês:

"Não se diga, pois, mais, que o problema do sobrenatural, tal como resulta do secreto trabalho do pensamento, que indiquei precedentemente, não é concebivel, não é adimissivel, não é filosófico: êle é, ao revés, a condição mesma da Filosofia, tal como ela se apresenta na sua intransigente independência" (45).

A noção da existencia de Deus está presa á concepção do Universo, e dela a Filosofia deverá tomar conhecimento, mesmo quando seja para negá-la.

Ora, estando a Filosofia do Direito, por sua vez, sujeita á Filosofia Geral, o magno problema não poderá ser impugnado no campo de nosso estudo (46), mormente quando êle serve de base para outro problema de indisfarcável importância: - o problema da ação.

16 - E' êste assunto que irá servir de tema a um novo capítulo de nossa dissertação.

A teoria teleológica, aplicada ao problema da ação, nos fornecerá a chave para abrir o pórtico que nos conduzirá á senda da Verdade. 
Daí o nosso grande interêsse em ferir tão importante assunto.

Já dissemos acima, que o homem, enquanto vivo, está sempre em ação. O dinamismo é o símbolo de sua existência: agir é viver.

Já vimos, igualmente, que na ação se acham estereotipadas as tendências dos homens.

Finalmente, tentamos explicar, que, além dos fins parciais, a que tendem os atos humanos, há um fim total, o Soberano Bem, que identificamos em Deus.

Passamos, com tais elementos, a examinar a atuação dos homens em sociedade.

17 - Em todas as latitudes e em todos os tempos, vemos. os homens agrupados, como si êles possuissem uma qualidade dispositiva inata para êsses agrupamentos.

Das hordas nômades primitivas até á sua fixação a um. determinado espaço de terra, com as sucessivas fórmas evolutivas de gens, tríbu e cidade - tais agrupamentos, apenas variaram qualitativa ou quantitativamente, mas nunca deixaram de existir.

Daí ter Aristóteles, na antiguidade, já esclarecido:

"O homem é naturalmente um animal político, destinado a viver em sociedade, e aquele que, por sua natureza e não por efeito de alguma circunstância, não faz parte de alguma cidade, é uma criatura degradada ou superior ao homem" (47).

Grotius, por isso, emprestava ao homem um natural "appetitus societatis"

18 - Rousseau, porém, não entendia assim, e antepunha um "estado de natureza" á sociedade (48).

Augusto Comte fez a crítica de tal teoria: 
"A doutrina, que é fundada em sua totalidade sôbre a suposição abstrata $e$ metafísica de um contrato social primitivo, anterior a todo o desenvolvimento das faculdades humanas pela civilização.

"Os meios habituais de raciocinio, que ela emprega, são "os direitos, encarados como naturais e comuns a todos os homens no mesmo grau, que ela faz garantir pelo contrato" (49).

Parece-nos que a concepção do "Santo Solitário" (50) era corrente em seu tempo - como se infere da leitura de uma passagem do "l'Esprit des lois" (51).

Comte, cotejando a obra de Montesquieu com a de Rousseau (52), deixou patente que a dêste visava apenas fins políticos, esquecendo-se, porém, de que ela, tanto bafejava as tendências liberais e até os extremismos libertários, como dava alicerce seguro para o mais violento despotismo. (53).

Tal teoria deveria ser repelida, desde logo, não só por não estar de acôrdo com as investigações históricas, como ainda pelo paradoxo de construir um contrato antes de existir uma organização jurídica.

HobBes firmou a origem da sociedade em um verdadeiro tratado de paz, que poz termo ás guerras de todos entre todos (bellum omnium contra omnes); tratado que não explica o agrupamento social, porque as guerras só existem de grupos contra grupos.

Taparelli declara que a sociedade é um resultado de fatos anteriores (54); deixando-nos um adito aberto ás conjeturas.

O fundamento da familia é biológico, mas o da sociedade não o será fatalmente, sendo fácil compreender quão vários seriam os ingredientes necessários para darem vida ao aglutinado social, se não fosse êle resultante da natureza do homem.

Não exerce a menor influência sôbre as conclusões dêste trabalho a genética social, senão para demonstrar que dela 
é que se origina a grande questão de se saber se a unidade resultante da pluralidade dos individuos assume uma fórma puramente convencional (individualismo), uma fórma puramente gregária (coletivismo), ou, finalmente, uma fórma mixta.

Pela primeira, o homem é tudo e a sociedade nada é; pela segunda, a sociedade tem a primazia sôbre o individuo, que perde a expressão de sua personalidade; e pela última, $o$ individuo mantem em face da sociedade direitos inalienáveis, que só sofrem contraste em relação recíproca entre si, e, portanto, em relação á sociedade como expressão de todas as personalidades que a compõem.

Aplicando-se a essas três correntes a teoria teleológica, poderemos afirmar: a primeira cogita apenas da finalidade humana, num egocentrismo incompreensivel; a segunda somente admite a finalidade social, desprezando a humana; e, finalmente, a terceira investiga a finalidade social, como um fim próximo, norteado pela finalidade humana.

A primeira, chamada racionalista, é a que melhormente já foi denominada "teoria robsoniana" (55), porque considera o homem isoladamente.

Bonnecasse sentenciosamente dizia:

" $E$ ' evidente que, sôbre o térreno do Direito, somos diretamente conduzidos ao "romantismo jurídico", desde o dia em que o homem é tomado como centro e rei do Universo (56).

MACH criticava o "racionalismo" com as seguintes palavras :

"A concepção do mundo dos autores da enciclopédia aparece-nos como uma especie de mitologia mecanicista, em paralelo com a mitologia animista das velhas religiöes"

Todo o "processus" dessa teoria errada desenrola-se no interior do indivíduo (57), numa abstração ousada (58), cujas aplicações, tanto no campo político (59), como no 
econômico (60), trouxeram os maiores males para toda a sociedade.

Contra a concepção racionalista, puramente gratuita, levantaram-se os homens de ciência; e, na fúria da peleja, levaram de roldão o Direito Natural, bem como tudo o que partisse da razão.

Eis a causa da descrença na metafísica.

$\mathrm{O}$ empirismo que, no terreno das ciências especulativas, dominava desde Bacon, foi transplantado cégamente para o campo das ciências práticas ou morais.

19 - Como estamos desenvolvendo um trabalho juridico, interessa-nos apenas constatar o aparecimento da Escola Histórica.

Sir Paylo Vinogradoff acentua com muita justeza, que da mesma forma com que, no seculo XVIII, a irritação causada pelo feudalismo soberano contribuiu poderosamente para produzir o racionalismo, igualmente a idéia de que o Estado e o Direito poderiam ser mudados deliberadamente pelos impulsos da razão pura determinou a veneração pelos elementos irracionais, inconcientes ou sub-concientes da vida social, e, com especialidade, da nacional. (61).

Essa corrente formidavel desceu das cumiadas de um nacionalismo desmedido.

Ninguem ignora a influência que, após o Tratado de Westphalia, a França exercia sobre o intelectualismo alemão.

Frederico II, depois cognominado "o Grande", em virtude da Guerra dos Sete Anos, era ao tempo de sua mocidade um admirador fanático do gênio gaulês, quando se lhe não percebiam ainda os talentos militares que o celebrizaram.

Era um simples "intelectual", então; amigo de Voltaire e, como êle, livre pensador, conhecendo-se, até, a sua célebre frase: "cada um deve ir para o Céo pelo caminho que preferir".

Desenhava-se, nítidamente, a ruina do Imperio Alemão, que possuia, então, cerca de trezentos Estados independentes, todos ciosos de sua autonomia. A desagregação 
desenhava-se, principalmente pela importação a granel de idéias francesas, de modas francesas e da própria lingua francesa. $O$ próprio Príncipe, em seu tempo de aprendizado, escrevera uma refutação a Machiavel (Anti-Machiavel) em lingua do país visinho, sob a alegação de que o seu idioma patrio era imperfeito e grosseiro. Patriotismo era sinônimo de inferioridade!

Assim começava o reinado daquele a quem Carlyle denominara "The last of the kings"

O particularismo local corria parelhas com o cosmopolitismo espiritual, no "Siécle des lumières" (Auflärung)

Algumas vozes de protesto, como a de Jústus Moser, o pai da "escola histórica" (62), começaram a encontrar éco na reação contra o "cosimopolitismo humanitário", os "direitos do homem”, e a desvalorização da lingua alemã pelos intelectuais.

A vitória da reação, sob o aspecto do nacionalismo, coube a Fichte, em 1807, com o seu célebre Discurso á nação tedesca (63), que foi o pregoeiro da "Kultur"

No domínio da ciência, surge Adam Müller, que estabelece o grande postulado, mais tarde retomado pela Sociologia, da concepção da sociedade como um todo orgânico, vivo e independente da influência individual (64).

$O$ exotismo francês entrou em franco declínio, substituido pelo realismo alemão; e, com êle, como seus ingredientes, foram expelidos: o cosmopolitismo humanitário, o racionalismo jurídico, o individualismo econômico e político, a literatura importada', com suas idéias, seu estilo e sua lingua, até a moda.

LANDSBERG aprecia a luta iniciada, contra o que êle denomina "charlatanismo" em direito e em política, pela Escola Histórica (65).

Não nos devemos esquecer de que Vico já tinha descoberto alguns traços do processo orgânico na História, como Hugo já tinha manifestado idéias similares, com a única diferença de método. 
A idéia matriz do "historicismo" funda-se em que não hä fases da existência humana destacadas, e a existência dos indivíduos, como a dos Estados, desenvolve-se com os elementos fornecidos pelo passado.

Comte tambem disse, que os vivos são cada vez mais governados pelos mortos.

Não há mais, portanto, questão sôbre o "bem" e o "mal", mas apenas do que é "possivel" ou "impossivel"

Rudolf von Ihering demonstrou, com a recepção do Direito Romano do Baixo Império pela Alemanha, o que havia de fantasia (66) no historicismo" o "volksrecht" era, assim, influenciado pelo "juristrecht"

Nos trabalhos de codificação civil alemã, GIerke, partidario da escola histórica, vencedor de WindsheId, na grande peleja, esclarecia extraordináriamente seu pensamento, quando afirmava:

"sentimos tambem que somos partes de um todo vivo, que age sôbre nós" (67).

20 - Está aí o nexo lógico entre as escolas histórica e sociológica, na reação exercida com furor contra o "racionalismo",

A identificação è perfeita.

Eis o postulado do "sociologismo", afirmado por DURKHEIM :

"A sociedade não é uma simples soima de indivíduos, mas o sistema formado por sua associação representa uma "realidade" específica, que tem seus caractéres próprios" (68).

0 indivíduo - para os sociólogos - deforma-se ao contato social, sofrendo a pressão das tendências coletivas - como advertia Lazarus.. (69).

Brinkmann - citado por Wilhelm Sauer - declara que o "irracionalismo" é o conceito fundamental da Sociologia (70). 
A "conciência social" e a "realidade social" são concepções metafísicas (71) ou criadas por um profundo misticismo (72).

O que nos importa constatar é que, como reação ao "racionalismo", a escola histórica e a sociológica alienaram todas as prerrogativas da personalidade humana (73), bem como todos os valores de cultura e, principalmente, toda idéia de finalidade do individuo.

Tristão DE ATHAyde apresenta-nos uma significativa opinião a respeito: o miserável papel reservado ao homem, por NaTORP:

"O homem individual é, a bem dizer, mais que uma abstração, como o átomo do físico" (74).

Qual o valor, pois, da ação humana?

A sociologia juridica absorveu a filosofia do direito, que se procura, atualmente, restaurar (75).

O empirismo sufocou a razão, a tal ponto de considerar-se o que não podia desaparecer de todo, mesmo da vida, mesmo da realidade, - o ideal jurídico - como uma simples crença, dando margem a práticas destituidas de princípios científicos. (76).

21 - Ressurge, assim, sob novas roupagens, a velha fórmula teleológica, explicativa da vida social, demonstrando que nem só a razão e nem só a experiência, mas ambas juntas, é que poderão esclarecer qual deva ser o rumo da atividade moral e juridica dos homens.

"Precisamos adquirir a confiança indispensável á ação" - diz-nos Françols Geny - e para isso deveremos tomar partido sôbre a concepção geral do Universo (77). 
Não é diversa a opinião do Príncipe das letras jurídicas pátrias, o professor Clovis Bevilaqua (78).

22 - O problema da ação está preso ao do conhecimento, e a reciproca é igualmente verdadeira.

Parece-nos dispensável a demonstração de que o homem age por que conhece o que pretende alcançar com sua ação: - um fim.

Ao revés, quando êle dá trabalho á inteligência, não o 'faz de fórma desinteressada: deseja conhecer para tomar um partido - como adverte Bergson (79).

A euforia espiritual dos helênicos, com a posse das verdades últimas, não provinha do simples conhecimento, tmas da harmonia dêste com a sua conduta. E o mesmo se dá ainda hoje, com a única diferença de que a "certeza" se encontra em um grau maior de complexidade de postulados sujeitos a constante revisão, e, tambem, entregues a métodos tirânicos.

Até poucos anos, o jurista, que procurasse, de acôrdo com a lição concorde de Geny e de Clovis, um sentido metafísico para o Universo, era punido com a excomunhão científica.

O Direito, para não ficar paralizado, teve que se espraiar pela sociologia, pela geografia humana, pela antropologia, pela etnologia e etnografia, pela psicologia, pela higiene, confundindo-se com as ciências naturais.

Tudo isso porque, no grosso comércio científico, a única moeda corrente era o empirismo!

$\mathrm{Na}$ Alemanha, por exemplo, as aulas da cadeira de filosofia do direito não possuiam senão um minguado auditorio, o que levou o professor Triepel, em Outubro de 1926, ao tomar posse do reitorado da Universidade de Berlim, a firmar, em discurso, hoje célebre, o dilema seguinte:

"Ou continuar degenerando, ou empreender o Direito uma caminhada filosófica, especialmente metafísica" 
Eis porque, hodiernamente, os mais formosos espiritos aconselham-nos, a nós juristas de visão estreitada pelo empirismo, a tentativa de integrar o Direito no Universo, para que possamos adquirir um sentido unitário para a vida, e, portanto, para a ação.

Do ressurgimento da filosofia do direito, nesses últimos anos, dá-nos conta o brilhante talento de Luiz R. Siches $(75$ e 80$)$.

Nem por isso deveremos abrir mão do grande patrimônio científico, que nos legou o empirismo, especialmente, das valiosas contribuições do método sociológico.

O Padre Cathrein S. J., com grande elevação de vistas, aconselha em sua obra imortal "Moral philosophie", que deveriam ser rejeitadas como igualmente errôneas as concepções, que exageram a importancia e o valor da razão natural, que tomaram vários coloridos no tempo: o "racionalismo", com suas diversas nuances, notadamente a filosofia livre pensadora do seculo XVIII, o ateismo, as escolas especulativas de Fichte, Scheling, Hegel e outras idênticas, bem como as que rebaixam ao nivel de inutilidades a razão humana, como o tradicionalismo, a escola histórica, o empirismo, o positivismo e o ceticismo moral (81). Nessas poucas palavras está dito tudo.

O homem, para conduzir-se na vida, se, de um lado, necessita da razão, de outro, não pode prescindir da experiência.

Se a ação é um impulso secreto da inteligência e da vontade, ela presupõe, ao mesmo tempo, uma relação, quando objetivada no mundo exterior.

De fato, se o movimento psiquico gravita em torno de fins, porque êstes é que explicam a ação, — os fins, por seu lado, realizam-se através dos meios. (82).

O sujetivismo de uns acasala-se com o objetivismo de outros.

Já se vê que estamos em plena filosofia social.

Linhas acima, deixamos demonstrado que o homem 
visa um fim último e total, bem como que o ser humano tem uma inclinação inata para a vida em sociedade.

A conseqüência lógica das duas premissas, no tocante á ação humana, é que a vida em sociedade não passa de um silmples "meio" para ser alcançado o fim supremo.

$\mathrm{E}$ é por essa razão que já tinhamos concluido, que a sociedade fôra feita para o homem, e não êste para a sociedade.

Se, pois, todos os membros do corpo social possuem uma finalidade suprema idêntica, - o nosso pensamento deverá flectir para a conclusão de que a sociedade não poderá atentar contra a finalidade comum de seus componentes, e, assim, ela servirá de explicação para as tendências sociais: Já dizia a sabedoria romana: "Quum igitur hominum causa omne jus constitutum sit. " (Dig., Liv. I, tit. 5, fr. 2).

23 - Examinemos atentamento o corpo social, mesmo nos primórdios de sua existência, a horda, nômade, sem organização estrutural definida.

Já existe entre seus membros uma liame misterioso, que se não apreende clara e totalmente, por mais eficientes que sejam os nossos recursos de análise.

Unidos para a defesa comum, não podemos dizer qual a extensão dessa defesa, tão complexo e vário se apresenta esse nexo de aglutinação.

A horda não é uma simples juxtaposição de indivíduos; e diriamos bem que, dentro dela, já existe uma lei, pois "lex" - afirmava SÃo Tomaz dE Aquino, com alta sabedoria - dicitur, a ligando"

Com o desenvolvimento social, as fórmas associativas já se vão tornando mais perfeitas, mas o "querer entrelaçante" entre os seus membros - como diz Stammler manifesta-se com complexidade crescente.

Nenhum individuo poderia dar seu assentimento á vida social, se pretendesse préviamente conhecer toda a extensão e variedade dos elementos de ligação que o vinculam aos demais. 
Por isso só se compreende quão justa é a explicação de Aristóteles da natural inclinação do homem ao convivio de seus similhantes - tão maravilhosamente desenvolvida por São Tomaz. (83).

Porque, dessa simples tendência, chegamos á formação de um tipo social mais perfeito, como o atual, e, tambem, porque do convivio dos homens surgiram idéias superiores de solidariedade, de moralidade, emfim, de aperfeiçoamento individual e social?

Porque, ao revés, os homens não deixaram a estrada da Civilização para embrenharem-se na "selva oscura" da barbárie?

Poderemos discutir siquer sôbre a existência dos valores culturais, já definitivamente adquiridos, do "bem", do "justo" e do "belo"?

Qual o seu fundamento?

Não haverá no mundo moral um conjunto de leis, na razão humana e acima dela, cujos efeitos determinam a marcha ascensional da Humanidade?

Não podemos atribuir tanta maravilha ao simples "acaso", mormente, quando lançamos nossos olhares para a unidade histórica do gênero humano - que tanto empolgou o genial Von Ihering (83).

A tendência associativa do homem, como uma qualidade dispositiva inata, e a sua crescente perfeição são dois argumentos para a compreensão da existência de uma lei superior.

O Doutor Angelico já a lobrigara claramente (84).

A teoria das leis - do imortal pensador, ontem autorizado catedrático da Sorbonne e hoje Santo - é a solução mais perfeita para o "problema da ação", que ainda tortura o espírito dos juristas.

Abrange, num só golpe, a moral e o direito, - porque a ambos está submetida a "unidade" da personalidade humana.

A lei, assim, não passá de uma regra, de uma verdadeira medida de atos (85). 
Ela desce do alto sôbre todo o Universo como sôbre os individuos. Si êstes têm, pela liberdade moral, a faculdade de infringi-la, nem, por isso, a lei perde o seu caráter de mandamento, eis que somente a infração da ordem social é que se reveste de uma fórma anti-natural - como já salientara Henri Bergson (86).

Devemos advertir que, quando Comte e Spencer usaram das expressões "dinâmica social e estática social”, talvez pensassem na existência de uma lei superior.

A simples existência de uma lei dá-nos a idéia de uma ordenação, e, consequentemente, de uma finalidade (87).

Poder-se-ia dizer, que com São Tomaz, fala apenas o teólogo, e não o cientista, o espírito investigador.

Deixamos, em apendice, um maravilhoso trabalho de Beudant, que confirma em absoluto a tese tomista, evidenciando que a lei natural sempre existiu, superpondo-se á lei escrita, como a modeladora da ação hulmana (88).

A concepção das "leis não escritas" — que formam o substrato do Direito Natural -- não é apenas uma manifestação da cultura ocidental. Incumbe-se de demonstrá-lo o jurisconsulto chinês LEANG K'I-TCHAO, com a sua interessante obra "La conception de la loi et les théories des légistes à la veille des T-Sin", em cujo prefácio o eminente PADoux resume os pontos mais importantes do referido trabalho (89).

E' o sentimento da natureza moral do Direito que o faz derivado da voz de Deus : nunca o cálculo ou a fraude piedosa; e as esferas da religião, da moral e do direito confundem-se $(90)$.

Toda a obra de Fustel de Coulanges, "La cité antique", é uma demonstração das origens divinas do espírito jurídico (91).

Precisamos salientar, que, ainda hoje, essas esferas são idênticas, não havendo uma diferença entre elas senão "quantitativa”, e nunca "qualitativa" (92).

"Das ethische Minimum" -- como afirma JELLINEK é bem o verdadeiro significado do Direito, sob a forma positiva (93). 
E não poderiamos compreender de outra sorte as três poderosas fôrças da conduta humana, não só em face da "unidade" do ser humano, que é incindivel, como ainda pela impossibilidade de darem uma direção á sociedade, numa linha reta, fôrças que fossem opostas entre si.

Ao contrário, há uma união intima entre a Religião, a Moral e o Direito - como já ficou demonstrado com o seu aparecimento sucessivo - atingindo o Homem, com eles, o valor supremo da auto-santificação (94).

Operada, que foi, a sua diferenciação, nem por isso se desligaram: antes, incessantemente o Direito vai buscar a necessária seiva na sua fonte nutriz, a Moral, e, esta, do mesmo modo, só se verifica quando recebe, por sua vez, a seiva da Religião.

Eis, portanto, justificada a teoria das leis de São Tomaz.

Já não seremos nós, que iremos falar agora: é um dos maiores jurisconsultos da França contemporânea, RIPERT:

"Quando São Tomaz fala do "jus naturale" êle não nega que os homens possam por suas luzes da razão descobrir as leis que convenham melhor á natureza humana; mas como essa natureza $e$ essa razão têm sido igualmente formadas por Deus, a moral tomista não poderia separar o ideal jurídico do ideal religioso" (95).

Essa lei nada mais é do que a representação esquemática da "finalidade suprema" - que está na razão humana, informando-a e disciplinando a ação.

E' o próprio Doutor Angelico quem o diz:

"Appetitus finis praecedit rationem ratiocinantem ad eligendum ea quae sunt ad finem" (96).

24 - A teoria teleológica, cujas aspirações são altissimas, porque procura penetrar na essência do Universo, não 
poderá - como é intuitivo - apresentar regras de detalhes á conduta humana.

Ações individuais há, na verdade, que são completamente indiferentes á finalidade de seus autores, porque visam fins parciais próximos; assim como conhecemos uma infinidade de atos individuais em frente aos quais a atitude :do Direito é de completa indiferença.

A teoria teleológica apenas dá uma direção geral á ação humana, e não possúe pretenções maiores.

Aliás nem poderia tê-las, porque o homem atingiria á "oniciência" si pudesse representar em seu espírito uma perfeita e total adeqüação entre a vida universal e a sua própria finalidade.

O ilustre Mestre, professor João Arrudi já advertiu, com a grande autoridade de sua posição de catedrático de Filosofia de Direito:

"Mas do fato de nós não termos uma clara noção de qual seja o "fim" que o homem se propõe neste mundo, o fato de nós não conhecermos qual a verdadeira linha do progresso, qual a verdadeira fórmula do progresso, não se pode inferir que esta fórmula não exista ou esta linha não esteja traçada, conquanto nós não a conheçamos perfeitamente" (97).

o princípio de finalidade, não decendo a detalhes, deixa, pois, largo campo para a observação das circunstâncias concretas da vida.

No campo da ciência jurídica êle assume a posição culminante de um elevado ponto de vista criteriológico, que fornecerá o mais seguro subsídio para a técnica do direito positivo, corrigindo os excessos da elaboração jurídica artificial, e, ao mesmo tempo, um guia infalivel para o cientista penetrar na natureza das cousas, sem iludir-se com as aparencias deformadoras da realidade social ou jurídica. 
A teoria teleológica permite, assim, a maior plasticidade de espírito, porque, desenvolvendo-se a finalidade numa determinada linha vertical, pode o observador necorrer ao ponto inferior, e dêle subir pela indução, como se colocar no ponto apical, fazendo derivar dêsse ponto de vista a priori o processo dedutivo.

Ao jurista, seja êle legislador, juiz, advogado ou jurisconsulto, só interessa a direção, porque ela é que dá a medida do "justo"

O filosofo, porém, não se contenta com tão pouco, e quer remontar, não apenas á causa primeira, mas, igualmente, á causa final.

O Direito, como ciência prática, não trabalha em primeira mão com a realidade social.

O "que é" foi relegado para o campo da Sociologia, com o caráter de ciência puramente discritiva ou método de investigação (98).

O "que deve ser", ou melhor, o "quid faciendum" é que toca de perto á ciência jurídica.

Duas grandes correntes mantêm a respeito desse tema posições bem definidas, e dí-lo Luiz R. Sıches:

"de um lado a invasão da Filosofia Jurídica pela Lógica e pela Gnoseologia ou Teoria Geral do Conhecimento (Stammler, Kelsen e toda escola vienense); e de outro a convicção de que a Filosofia Prática, tanto moral, como jurídica, possúe elementos próprios autônomos e carateristicos, que não podem resolver-se ou se dissolver em meras teorias lógicas e gnoseológicas (LASK, Radbruch, MUench, Scheler, Guardini).

"Singularmente a especulação presente gravita em torno da discussão entre logicismo e eticismo: isto é, sôbre si a Filosofia do Direito pode ser construida meramente com ingredientes de caráter lógico (latu sensu) ou sôbre uma base etica irredutivel áqueles" (99). 
Em todas as construções filosofico-jurídicas das duas correntes formidaveis, ambas neo-kantiannas, dos marburguenses e da escola do Sudoeste da Alemanha - predomina o elemento teleológico.

Stammler, por exemplo, não vê na vida social senão uma relação de meios a fins (100).

A mesma concepção teleológica predomina tambem entre os positivistas, como LÉon Dugurt, de cuja obra principal extraimos a seguinte passagem bem significativa:

"Isto posto, a lei social, da qual reconhecemos a existência, não pode ser uma lei de causa, pois que ela se aplica aos atos voluntários e concientes do homem. Ela não pode ser senão uma lei de fim, uma regra, uma norma que dirige e limita a atividade conciente e voluntária do homem, que fixa o objeto e o fim de seu querer, que lhe interdiz certos atos e lhe impõe certos outros.

A norma social existe somente por que as sociedades humanas são compostas de seres concientes. O homem vive e não pode viver senão em sociedade. Uma sociedade não pode existir si os individuos que a compõem não se conformam á lei do ser social. Como êsses indivíduos são concientes e querem certas cousas determinadas por um fim, a lei da sociedade regula necessáriamente e somente o objeto de seu querer e ofim que o determina (101).

Quais são êsses fins - sôbre cuja existência existe quasi uma opinião unanime?

Aí colmeça o dissídio.

Rudolf von Ihering responde que o fim do Direito deve ser a garantia das condições da vida da sociedade (102), a auto-conservação. (103).

Rudolf Stammler pretende, com a sua Soziale Teleologie, galgar um ponto de vista superior, e trata então de descobrir um fim supremo da sociedade dos homens, com o 
caráter de generalidade formal, que será o sinal distintivo de seu valor (104).

Todos os neo-kantiannos, na investigação do elemento teleológico, chegam somente aos "valores culturais" - que hoje são tidos como o único sucedâneo da construção novada Filosofia do Direito.

Temos a impressão de que reina um temor geral nos espiritos, quanto situam tão baixo os fins sociais.

Duguit, que já reconhecia - apezar de positivista a existência de uma lei do "ser social", isto é, do homem, agora já tergiversa:

"Eu poderia mesmo dizer que há uma lei de fim; mas poder-se-ia, então, me recriminar justamente de fazer intervir um conceito a priori de finalidade. Eu falo de norma simplesmente porque ela se aplica a todos os seres concientes" (105).

Não nos paguemos apenas com palavras:

Toda tentativa está em dar ao direito uma base sólida, por meio de um conceito absoluto - e, nessa tentativa, vemos Stammler apropriar-se da distinção aristotélica da "Form und Materie" (106), afim de conseguir um elemento permanente para a construção de seu sistema.

A "Kultur" poderia fornecer êsses fins, si ela, por sua vez, como muito bem assinala Dugurt, é movediça? (106).

Luis R. Siches não compreende como se pode extrair do "factum" da Cultura os apregoados "valores absolutos", e, analisando-os, conclúe:

"A união total e perfeita entre o Ser e o Valor está representada pela idéia de Deus" (107).

E Sertillanges, com a sua reconhecida autoridade, pontifica :

“ retirando-se a idéia de Deus, ver-se-á que se retira com o mesmo golpe o que pode dar aos fins sociais um preço que valha a pena" (108). 
Os fins sociais, e, portanto, do Direito como ciência social, não estão em nível humano, como se pretende, umas no plano do sobrenatural.

RIPERT já o esclarecia, e ninguem pode contestar o valor científico dêste grande professor da Faculdade de Direito de Paris:

"Quando o direito fortifica o dever de assistência entre os cônjuges, autoriza a investigação da paternidade natural, organiza a proteção da infancia, interdiz o contrato imoral, refreia a especulação, aumenta a responsabilidade, não tolera o enriquecimento injusto, proïbe o abuso de direito, protege o operário contra a exploração do patrão, assegura $o$ repouso hebdomadario, luta contra a licenciosidade dos costumes, tenta assegurar a justiça na repartição do imposto, êle realiza os fins da moral cristã" (109).

E' certo, que acaba de falar um católico, e o seu depoimento é suspeito. Toma-lhe a palavra um autêntico positivista, o saudoso professor da Universidade de Bordeaux, Duguit :

"E si me fosse permitido fazer uma incursão no domínio religioso, eu diria que os mitos cristãos somente é que fizeram penetrar na alma humana essa concepção fundamental de todo ideal humano e de toda civilização, e que não existiu verdadeiramente civilização senão depois do cristianismo e pelo cristianismo, o único que fez compreender ao homem que êle não é homem e que não possúe algum valor senão pelos laços que o unem aos outros, aos vivos e aos mortos, pelos serviços que êle presta aos vivos. Eu digo isso, não como crente, mas como sociólogo, pro- 
fundamente respeitoso de todas as crenças sinceras, mas que pensa estar liberto de todo dogma e de todo preconceito" (110).

Fato digno de menção é observarmos como Rudolf Stammler se socorre da parábola evangélica do "Bom Samaritano" para esclarecer e determinar os deveres juridicos do homem para com o seu próximo (111).

A readmissão do elemento teleológico no Direito, en quasi todos os quadrantes do pensamento jurídico moderno é bem significativo, e com ela reflorece a arvore da Filosofia do Direito, que embebe de novo as suas raizes, sedentas de seiva, no sólo dos princípios morais.

O professor ordinário na Real Universidade de Roma, Grorgro del Vecchio, sente que o Direito não pode prescindir de tal elemento, e di-lo em termos os mais precisos:

“A interpretação teleológica é portanto, não só legítima, mas indeclinável; e o recurso a ela se revela com tanto maior necessidade quanto mais elevadas e complexas são as relações em que se trata de penetrar" (112).

Há, nos trabalhos modernos "uma aspiração para uma finalidade inteligivel, única capaz de dar sentido ao mundo" (113).

Mercê da nova tendência generalizada, o jurista pode encontrar uma direção segura para todos os problemas que se lhe apresentarem, como legislador, como juiz, como advogado ou como jurisconsulto.

25 - A direção teleológica aponta-nos, ainda, a marcha previsivel da ciência jurídica para a sua perfeição. Ela vem sendo lenta, á custa de dôres e sacrifícios, transpondo obstaculos, que pareciam irremoviveis, e chegando a transformações rápidas, que nos assombram. 
Si pensarmos, porém, como foi empreendida a caminhada das idéias morais, através dos tempos - desde a vida na horda primitiva até á atual organização política da sociedade, - sentiremos o nosso espírito cheio de confiança na futura melhoria das relações sociais.

Não olhemos para nós, individualmente, porque chegariamos á conclusão decepcionante de Schopenhauer (114).

Não devemos lançar nossos olhares aflitos para um soldado que cai varado pelas balas do inimigo, mas para a vitória do exército, que, no caso, é a grande familia humana.

Em que pese aos hedonistas de variados matizes, - a marcha ascencional das idéias morais é feita sob o aguilhão da dôr!

Ela é a fôrça propulsora da finalidade.

Se não existisse a dôr moral, a finalidade implicaria no determinismo, porque não se poderia compadecer com a liberdade inserta na natureza espiritual do homem. (115).

A dôr é uma conselheira e uma mestra, que sussurra aos espíritos a sua vocacão sobrenatural.

Ela domou as explosões do egoismo antigo, permitindo modelar a fórma jurídica de pacificação dos litígios.

E, sem pretenções a profetizar futuros acontecimentos - poderemos assegurar que ela será a dominadora do egoismo internacional!

O Direito vai buscar na coacção, necessária ainda para sua mantença, uma imagem da dôr

Graças a ela o homem põe em eqüação a sua finalidade, seja parcial ou suprema, com a sua conduta.

E', como muito bem diz Gabriel TARDE, um sílogismo da atividade, que se estabelece.

No campo do direito, a maior é a regra jurídica, a menor a conduta do indivíduo, delas se extraindo, com rigor lógico, uma conclusão.

Remontemos, com TARDE, a um plano mais elevado:

“Está lá o dever moral própriamente dito, dever puro e simples, que perdeu o sentimento de seu parentesco com a relação de finalidade" (116). 
26 - Voltamos, assim, por uma natural associação de idéias, ao problema da ação humana - pedra angular do Diretor, sob o ponto de vista filosófico.

Agora, já podemos ver claramente, que a finalidade social não pode estar em oposição á finalidade dos indivíduos que compõem a sociedade.

Todos, e, portanto, ela, visam um "bem" - e êsse bem já pode ser expresso na fórmula tomista do "bonum communitatis"

Ahrens muito bem já observava:

“As duas noções são eqüivalentes no sentido em que tudo o que é bem deve tornar-se um fim para a atividade humana, e que um fim implica sempre em um bem (117).

Ora, São Tomaz de Aquino já advertia:

“A pessôa compara-se á comunidade como a parte ao todo" (118).

E, como conseqüència lógica, acrescenta :

"Quem busca o Bem Comum, busca o próprio bem, porque o bem próprio não pode ser sem o comum, como a bôa disposição da parte depende do todo" (119).

A questão, que deve interessar ao jurista, cifra-se em procurar sob que critério o "bem comum" deverá influir no direito.

Ainda que a muitos pareça tal critério ser o da "utilidadie", êle deverá ficar confinado dentro das raias da Justiça.

A idéia do "justo", lei fundamental da ciência jurídica, origina-se da "retidão moral"

A sua aplicação, porém, dependendo da sociedade, fica entregue ao Estado. 
E' por isso que Kelsen identifica o Direito com o Estado (alles Recht ist Staatsrecht).

Mas não se poderá compreender um direito superior ao Estado?

KELSEN próprio o reconhece, mas, para não quebrar as linhas arquitetônicas de seu monismo jurídico, quer admitir a existência de um Estado Universal - pura fantasia de seu espírito (120). Vejamos ainda: "O direito social puro "está colocado em posição independente do Estado, e - segundo atesta Gurvirch - é um direito de integração, de comunhão, e de colaboração numa totalidade anti-hierárquica (121).

Já se admite, hodiernamente, que paire sôbre a "soberaniaj política" dos Estados uma "soberania jurídica"

E não poderemos identificar essa "soberania jurídica" como a fonte donde partem as "leis naturais" ou, ainda, as "leis não escritas"?

Já sentimos como o problema do conteúdo do direito se vai complicando, e não vemos como deve o agnosticismo resolvê-lo, si não pode conferir fins inteligíveis á vida humana.

O tomismo, ao revés, tem capacidade para chegar naturalmente á uma conclusão positiva.

Quando o "bem cómum" é visto pelo prisma da Justiça - tem-se o direito, que surge como regra e medida das ações individuais.

A Justiça, por seu lado, está entre as virtudes, que o homem deverá pôr em prática, para alcançar a sua suprema finalidade.

A Justiça, tanto comutativa, quanto distributiva, deve modelar-se de acôrdo com o princípio superior da fraternidade.

As reivindicações da era atual convergem no; sentido de uma mais perfeita Justiça comutativa.

Seguimos para a frente, galgando a áspera e ondulada estrada, que, muita vez, perdemos de vista, mas que vai escalando o Calvario de nossa perfeição. 
Muitos desertam, é fato, mas o grosso da familia humana continua, sempre para a frente, a sua marcha ascencional, através dos seculos, uns concientes de seu fadario, outros inconcientemente empolgados pelos ideais superiores da vida, respirando, sem o saberem, o perfume cristão, que ambalsama a atmosfera de nossa Civilização (122).

$O$ jurista deve seguir o conselho de Maxime Leroy:

“doit voir un impétueux mouvement du fait, qu'il sait devoir se modifier à mesure qu'il coule vers un avenir dont il ne comprendra pas la tendance, sil n'est pas passionnément curieux" (123).

A finalidade do Direito é, em summa, medir, pelo critério da Justiça, a vida fraternal dos homens, ou em outras palavras, o "bem comum"

27 - Deverá causar extranheza o fato de não termos feito neste trabalho uma especial referência a Rudolf voN IHERING - o verdadeiro chefe da escola teleológica do Direito.

Delle discrepamos, porque o sábio professor de Goetting só admitia a finalidade no mundo moral;

"Na natureza inanimada esta causa é de essência mecanica (Causa efficiens); psicológica quando se refere á vontade: esta obra em virtude de um fim, de um objeto" (124).

Enunciar essa tese e pô-la nos labios de Von Ihering era esperar o largo e altaneiro vòo de um pensamento condoreiro.

"Disse-se dêle, que êle não poderia entrar em "uma idéia sem que a alargasse. Disse-se de seus escritos que êles se assemelham a relâmpagos: êles surpreendem, êles deslumbram, êles espalham uma fulguração inesperada sôbre os vastos espaços onde parecia reinar apenas a noite" (125). 
Quanto de razão existe na crítica feita ao genial professor tedesco, em relação á obra que deveria ser a cúpula de suas brilhantes produções jurídicas.

Contradições verdadeiras foram apontadas (126); notou-se uma inesperada obscuridade em suas idéias sempre tão claras e transparentes (127); emprestou-se á sua obra considerações puramente utilitarias, (128); negou-se-lhe até o título de filósofo, a êle que arrancara, magistralmente, de um material bruto, o "espírito" do Direito Romano (129); declarando-se, até, que êle, o condor da ciência jurídica, não conseguira elevar-se acima do plano do empirismo (130).

Foi Von Ihering, com o seu "Zweck im Recht", considerado plagiário de Hegel (131); e, finalmente, degradado á condição de representante do "materialismo jurídico" (132).

Por cúmulo, surge Paul Vandfr Eycken, que se propõe a reduzir, sob um ponto de vista do positivismo, a concepção teleológica do grande jurista-filósofo, decompondo-a a seguir em um certo número de elementos as condições existenciais da sociedade: subsistência, liberdade, segurança, igualdade, abundância, entre os quais estabelece, como critério de importancia, uma hierarquia (133).

Ficaria reduzida a uma ínfima proporção a obra de Ihering, se lhe não saisse em defesa, com impávida sombranceria, o jurisconsulto "francês", Françors Geny.

O eminente professor da Faculdade de Direito de Nancy mostra aos críticos, que imputaram ao seu ilustre colega alemão a pecha de materialista, a verdadeira compreensão da obra criticada:

"De fato, quando nós analisamos a obra, seguramente imponente, do ilustre autor do ZWEck IM RECHT, devemos reconhecer que R. von IHERING não nos tem, em nenhuma parte, descoberto quais são, em si mesmos, os fins capitais suscetiveis de determinar a conduta social. Si por vezes, por traz da noção extrinseca do fim, que parece absorver toda a sua atenção, êle deixa entrever um PRO- 
FUNDO IDEAL, jamais, que eu saiba, êle não tem desvendado o seu mistério" (134).

Rudolf von Ihering não o disse certamente - mas podemos, pela inteligência, enxergar, através de suas palavras, o espírito que as animava.

Identificamos o seu pensamento com o de SÃo TomaZ DE Aquino, segundo o qual: os fins constituem a própria natureza do ser, e, por ser o Direito uma ciência social, os seus fins, dependentes da natureza social do homem, são os necessários para a conservação da sociedade. (118).

Chega-se, assim, á compreensão do "bem-comum" pedra angular do tomismo como ciência social.

A finalidade identifica-se com o "bonum communitatis" Ahrens já observava muito bem:

“As duas noções são eqüivalentes no sentido em que tudo o que é BEM deve tornar-se um FIM para a atividade humana, e que um FIM implica sempre em um BEM" (135).

Já se encontra Von Ihering no mesmo ponto de vista de São Tomaz de Aquino, com a única exceção de que o Doutor Angelico descortina todo o panorama do Universo, emquanto o professor de Goetting apenas divisa um único ângulo.

E forçoso é reconhecer no autor de Zweck im Recht uma intuição, ainda que difusa, de toda a verdade eterna da finalidade, - tema central da Filosofia.

Assim, depois de conhecer a imortal obra de São Tomaz de AQuino, vêmo-lo, como numa nova Estrada de Damasco, prostar-se ao sólo da ciência jurídica, numa atitude de humildade sincera, declarando que não teria escrito todo o seu livro se tivesse notícia da obra do grande Santo, porque as idéias básicas, de que fazia questão, já se encontravam no 
"pensador grandioso", "com clareza absoluta e em termos os mais categóricos" (136).

28 - A presente dissertação já vai tomando uma extensão perterintencional, e, a-pezar-disso, não poderá tratar senão perfunctoriamente do tema escolhido.

Nota-se um grande acúmulo de citações, que poderia ser encarado como uma manifestação de cabotinismo.

Dissemos, logo nas primeiras linhas dêste trabalho, que êle é uma obra desvaliosa, mas feita de bôa fé. E é justamente para justificar a nossa lealdade, que recorremos á autoridade dos autores citados.

Já advertia Fontenelle:

“Nous ne pouvons voir d'un peu loin sans monter sur les épaules les uns des autres"

As lições dos Mestres servem de lentes de aumento para a nossa visão apoucada.

Vamos estugar o passo para concluir, sem mais demora.

A princípio colocamo-nos no centro do Universo familiar ao homem, para tanger a realidade, e vimos como ela, ainda que existente, é movediça, arrebatada pelo fluxo constante da vida.

Em seguida, demonstramos que a ciência verdadeira deveria transcender o conceito empírico da causalidade, que dava a explicação mecanicista do mundo, para embrenhar-se na essência das cousas, retirando, pela observação empírica e pela razão, o conceito de uma finalidade - que pode ser dispensado pelas ciências especulativas, mas nunca pela scientia altior.

Chega-se, assim, ao estudo dos valores gnoseológicos, os únicos que podem discernir na obra do saber, no terreno sólido da "certeza", o que depende do "real" e o que pede meças á atividade construtora de nosso espírito. Defrontamos com um "realismo mitigado". 
Se, por meio do processo de triangulação, chegamos a determinar, pela geodesia, um ponto inacessivel aos nossos olhos, - porque não poderemos atingir, pelo espírito, as mais altas verdades, mesmo a suprema, si chegamos á conclusão da existência real, ainda que discontínua, de uma linha retilínea e inflexivel de direção: a finalidade?

Como nos parecem fracas as respostas dadas por DesCARTEs a objeções feitas por Caterus á terceira de suas Meditações?

Sem grande esforço identificamos o Bem Supremo, a que tende o espírito humano, e tentamos polir novamente os brazões, em que o homem cinzelou a heráldica de sua progênie divina.

Naturalmente, chegamos ao problema da conduta humana - que é o pivot central da religião, da moral e do direito - distintos apenas quantitativamente, apezar de sua constante e progressiva diferenciação.

Vimos, que no mundo moral há uma lei de fins, e que êles se acham suspensos entre o Céo e a Terra.

Prova-o a existência de leis naturais, regendo as ações humanas; e, com espírito realista, fomos encontrá-las en todas as épocas e em todas as latitudes.

Finalmente, atingimos á idéia central da fraternidade humana, que deverá ser o princípio donde poderão ser lógicamente deduzidas todas as regras da moral e do direito.

O progresso da ciência jurídica não tem sido outro senão a crescente adaptação das normas áquele princípio superior.

Foi dêle que S. Tomaz, com admiração de Ihering, deduziu o conceito do "bem comum"

Atualmente já se diz: o direito não cogita do "meu" ou do "teu", mas do "nosso".

Como se chegará á compreensão do que é "nosso", na sociedade juridicamente organizada, sem remontar ao princípio da fraternidade humana?

Justamente para regrar e medir o "nosso", sob um critério de Justiça, é que foi criado o Direito.

Quais, pois, são os fins do Direito? 
Limitamo-nos a dar o princípio superior, porque a sua aplicação aos casos concretos será tarefa para absorver uma existência - si esta fosse bastante.

Basta que se determine a "finalidade" suprema do Direito, e não foi outro o escopo nosso, quando tentamos abordar o grandioso tema.

Lembrêmo-nos de que, na Convenção de Philadelphia, não foram inscritos ou declarados os "direitos dos homens" — sob a alegação de que uma constituição não cria direitos, não os fabrica: iencontra-os existentes! Quando são por demais visiveis alguns fins do direito, torna-se até desnecessária a norma jurídica.

Não fôra a extensão de nosso trabalho, e fariamos a aplicação de nossa tese no combate ao materialismo histórico, demonstrando como a evolução econômica não é a sintese potente da filosofia da história, como afirmam Engels e Marx.

Finalmente, se nenhum mérito científico possúe esta dissertação, pelo menos, tem o valor de engolfar-se na avalanche da reação contra a amoralidade jurídica, iniciada no seculo passado.

Até os sábios já abandonam os seus laboratórios, juntando as suas vozes autorizadas aos moralistas.

E' significativo o livro de Max Plank, "Were is science going" onde se lê o apêlo veemente:

"A humanidade necessita de maximas fundamentais para a sua conduta de cada momento, $e$ essa necessidade é mais premente que a fome do conhecimento cientifico"

Nessa maré montante de justa reação, seja êste pequeno trabalho de sinceridade e de fé uma pequena gota dágua, um átomo humilde e despretencioso.

Servem de guia a nosso espirito de jurista, equilibrando os nossos conhecimentos e a nossa ação, as palavras de São BERNARDo: 
"Lucere et ardere perfectum est. Sunt quidam qui sciunt ut sciunt, et est curiositas; sunt quidam qui sciunt ut sciantur, et est vanitas; sunt quidam qui sciunt ut lucrentur, et est cupiditas; sunt quidam qui sciunt ut aedificent, et est CHARITAS!

\section{OBRAS CITADAS COM A TRANSCRIPÇÃO DOS TEXTOS RESPECTIVOS}

(1) “O mundo fenomenal não passa de uma ilusão (PE. Leonel Da Franca - História da Filosofia, 3. ${ }^{a}$ edic., pag. 30).

(2) “Ora, o ente, não podendo vir do não ente "ex nihilo nihil", é uno, eterno, ingênito, imóvel, indivisível, imutável, homogêneo, contínuo e esferico (esfera-figura perfeita) PE. L. DA Franca, op. cit., p. 30$)$.

(3) "Féconde remarque que cette opposition radicale entre l'apparence et la réalité, l'être et le devenir! progrés décisif, qui ne sera pas perdu pour la philosophie: cettle opposition va devenir la préoccupation constante de la pensée réflechie (F. PaLHoriés Vies et doctrines des grands philosophes à travers les âges, tom. I, p. 36$)$.

(4) Pe. Leonel da Franca - op. cit. § "Le savant actuel ne peut indiquer l'essence du réel (E. Meyerson - Le physicien et le réel (In Le Mois - Junho 1931).

(5) Aristote - Métaphysique, liv. IV.

(6) "Cette disposition de la nature à produire toujours certains effets dans certaines circonstances, pourvu que ces circonstances soient entièrement définies, c'est ce qu'on appelle déterminisme, et beaucoup se figurent que déterminisme et finalité sont des termes qui s'opposent, alors qu'ils s'impliquent l'un l'autre, bien que ce soit inégalement. Tout ce qui se fait en vue d'une finn'est pas soumis au déterminisme; la liberté existe, bien que toujours un déterminisme fondamental et un déterminisme concomitant soient supposés à son travail. Mais en revanche, tout ce que est soumis au déterminisme" obéit à une finalité, et c'est cela même la définition du déterminisme" (A. D. Sertillanges - Dieu ou rien, vol. I, pgs. 25/26).

(7) “Además del concepto mécanico o estrictamente físico de la naturaleza, queda lugar para outro concepto, que podría llamarse 
metafísico, el cual non es menos válido ní menos necessario que el primero, porque está fundado, de parejo modo que éste, sobre una función y una actitud intrinseca de nuestra mente. La realidad nos aparece ciertamente de un lado, en una de sus vertientes, como sujeita al vínculo de la determinación causal, que liga inescindiblemente iodos los fenómenos de la mísma: pelo se revela, además, tambien como animada por una potencia espontánea e inagotable, que dirije y guia sus processos. y la levanta de grado en grado hacia sucessivos desarrollos y formas nuevas y más altas. La naturaleza es, en este sentido, principio vivente que agita la mole de universo y se espressa en la infinita variedad de su desenvolvimiento: es aquella substancia que reconocemos ya imune de las angustias de la causalidad: es la razon interior que dá normas a todas las cosas, y les asigna sus propias tendencias, funciones y fines. Una conception tal de la naturaleza, bien mirada o entendida, no contradice, sino que integra y completa la otra consideración (o sea la causal) (GIORGIO DEL Vecchio - Filosofia del derecho - trad. de Luis R. Siches, Barcelona, 1929, Tom. I, pag. 439) Conf. do mesmo: "Il concetto della natura e il principio del diritto, 1908".

(8) Paulo L. DÉcourt - As ideias preconcebidas em Historia Natural - Tese 1918, - cap.: - o principio da finalidade, pag. 29).

A êste ilustre naturalista e conhecido professor do Ginásio do Estado, em Campinas, devo preciosas informações sobre a reação anti-mecanicista em Biologia, chefiada por Hans Driesch, na Alemanha. Esse movimento desenvolve-se em torno do conceito de finalidade, não como explicação causal, mas como expressão "condição pre-explicativa geral que as funções do vivo, e o uso que êle faz de suas estruturas, servem á continuação da vida (JacQues Maritain Les degrés du savoir, 1932, pag. 383).

(9) "Pondo de parte a ineficácia da lei, que não exprime uma verdade, não é realizada pela História, nem pode abranger o curso geral da Civilização, inúmeras são as imperfeições da exposição comtisía (Farias Britto - O mundo como atividade permanente do espírito humano, pag. 70).

“ estou inteiramente em desacôrdo com êle sôbre os princípios em que se basêa a sua filosofia e que lhe determinam a organizaã.o (H'erbert SPencer - Classificação das Scienncias, trad. de M. C.. da Rocha, pag. 69) .

(10) “La métaphysique a pour mission d'opérer la syntèse mentale de toutes ces vues scientifiques et esthétiques et de déterminer l'armature la plus appropriée pour remplacer le mieux possible dans la statue du savoir humain l'ossature de l'organisme vivant qui est son modèle. On dit trop aisément qu'en Métaphysique on voit 
tout ce qu'on veut. C'est là faire preuve d'une profonde inexpérience philosophique" (Francis WarRaIN - L'Armature métaphysique pag. 10).

(11) Clodius Piat - Aristote, 2." edic., pag. 3).

(12) "Nous voyons, par ce qui précède, que le caractère fondamental de la philosophie positive est de regarder tous les phénomènes comme assujettis à des lois naturelles invariables, dont la découverte précise et la réduction au moindre nombre possible sont le but de tous nos efforts, en considérant comme absolument inaccessible et vide de sens pour nous la recherche de ce qu'on appelle les causes, soit premières, soit finales (Augusto Comte - Cours de Philosophie Positive, tom. I, pag. 8, 5." edic.).

(13) “ une philosophie ne peut être constituée par un nombre quelconque de principes connus seulement (H. SPENcer - Les premiers principes, trad. Vazelles, 2." edic. $\S 186$, pag. 483).

(14) “Em um sentido, entretanto, Laugel transmite aos seus leitores juizo errôneo, etc. Laugel me apresenta como discipulo de Comte em certos pontos (SPENCER - Classificação das sciencias, edic. e trad. cits. pag. 59).

(15) "Bien qu'il soit impossible de donner à cette conception une expression qualitative ou quantitiative quelconque, il n'en est pas moins certain qu'elle s'impose à no,us comme un élément positif et indestructible de la pensée (Spencer - Les premiers principes, trad. e edic. cits., pag. 80 .

(16) " o espírito adquire a conciência de uma causa universal, que não pode ser concebida" (Classificação das ciênciastrad. e edic. cits. pag. 70).

(17) "Les intuitions fondamentales essentielles à l'opération de la pensée doivent être temporairement admises comme incontestables; on laissera aux résultats le soin de justifier cette hypothèse (SPÉNCER - Les premiers principes - trad. e edic. cits, pag. 120).

(18) “En conséquence, la Philosophie, forcée de faire ces suppositions fondamentales, sans lesquelles la pensée est impossible, peut les justifier, en montrant leur conformité avec toutes les autres révélations de la conscience" (SPENCER - Les premiers principes trad. e edic. cits., pag. 121).

(19) “Et conscients des difficultés extrêmes, qu'offre à notre nature le déchiffrement de l'énigme du monde, nous veillerons à ne pas mutiler nos facultés d'investigation, mais, au contraire, à les accroître et fortifier, en ouvrant grand notre horizon, en usant largement de tous les secours" (FRANçoIs GENY - Science et technique en droit privé positif, tomo I, pag. 87, edicc. 1922).

"Ils méconnaissera à fond la valeur de l'abstrait, de cette immatérialité plus dure que les choses, bien qu'impalpable et inimagina- 
ble, que l'esprit va chercher au coeur des choses" (Jacqufs Maritarn - Distinguer pour unir, 1932, pag. 4).

"Ce n'est qu'en de fugitifs instants qu'Henri Poincaré jette un regard sur ce monde transcendant. $\mathrm{Y}$ vivre, comme dit Aristote, serait d'un dieu: il n'est donné à l'homme que de l'entrevoir, par instants, comme à la lueur d'un éclair" (EMrLe Boutroux $\longrightarrow$ Nouvelles études d'histoire de la philosophie, 1927, pag. 65).

(20) Vid. trabalhos de Theodule Ribot, de Pierre Janet e GusTAVE LE Bon, neste sentido, e que são por demais conhecidos.

(21) "Ne serait-il plus juste de dire que la vraie psychologie c'est précisément la mátaphysique?" (Jules LACHELIER - apud Boutroux - ob. cit., pag. 19).

"En résumé, les phénomenes psychologiques ne peuvent être intelligibles et réels que s'il existe une conscience sensible, dont ils sont l'oeuvre et la projection, loin que cette conscience puisse s'expliquer par eux" (Jules LACHELIER - op. cit. pag. 22).

(22) (A doutrina de Freud, 1930, pag. 11)

Confirma-se a crítica severa, que faz De la VaissiÉre, no seu trabalho "La théorie psychanalytique de Freud" in Archives de Philosophie, vol. VIII, cahier I, 1930).

(23) "La science véritable, la seule que nous connaissions, n'est en aucune façon et dans aucune de ses parties conforme au schéma positiviste" (De l'explication dans les sciences - Emile Meyersen, 1921, tom. I, pag. 31).

"La science, sans doute, n'arrive jamais à formuler une assertion définitive: elle ne peut dépasser le provisoire. Elle procède par approximations successives. (Boutroux - op. cit., pag. 59).

"Est-ce donc que la science ne porte pas sur le réel? Non, elle ne porte pas directement sur le réel, tout cru, sur la réel pris dans son existence concréte et singulière" (Jacques Maritain - Les degrés du savoir pags. 49/49). Confira-se Françors GENy - Science et technique, tom. I, p. 66).

"Les vérités ne s'y démontrent pas leur réalité objective, mais seulement par les conséquence qui résultent de leur application pratique - (CH. Fiessinger - Science et spiritualisme, 1907, pag. 15).

"Par rapport à l'experience, une théorie n'est que plus ou moins probable" (D. NEDELKovitch - La philisophie naturelle et relativiste de R. J. Boscovich, introd., pag. 15). Confira-se Henri PornCARÉ - La science et l'hypothese, 1902 e Dernières pensées, 1913; Pifrre Duhem -- La théorie physique. Son objet et sa structure, 1906.

(24) Pedro Lerra - Estudos de Filosofia do Direito, 2." edic., pag. 452).

(25) "On voit de suite la conséquence. Dans tous nos actes 
délibérés, la responsabilité de la raison est totale; par suite, toujours égale à elle même. Pas de circonstances atténuantes, puisque, dans cette théorie, c'est la raison ele même qui sert d'explication aux circonstances. Je ne serais pas dans tel cas, si ma liberté ne m'y avait mis en déterminant, hors du temps, le caractère de ma vie telle qu'elle se déroule dans le temps" (A. D. Sertillanges, S. Thomas d'Aquin, 4." edicc., tom. II, pags. $285 / 286$ ).

(26) (Sertilianges, - op. cit., tom. II, pag. 288).

(27) "La grande querelle entre le Libre arbitre et le Déterminisme n'est pas un obstacle à surmonter necéssairement pour l'exposé du mécanisme du Droit" (Edmond Picard - Droit Pur, Flamarion, 1908 , § 14, pgs. 29/30).

(28) “ aspiration vers une finalité intelligible seule capable de donner un sens au monde; - à quoi s'ajoutte, pour le domaine moral, le principe du devoir, basé sur la distinction du bien et du mal, révélée par la conscience qui dirige la volonté de l'homme, tenue pour libre en dépit des illusions déterministes (Françors GeNy Science et technique, tom. I, n. ${ }^{\circ} 24$, pag. $74-2 .^{\text {a }}$ tiragem).

(29) “ la misma ley de la causalidad se pone y emana de la conciencia, y es intrinseca al sujeto, que modéla segun ella en un cierto sentido sus experimentos y sus operaciones (Filosofia del derecho de Giorgio del Vecchio - trad. de Siches, tom. I, pag. 443).

(30) "Dunque: tutto deve procedere ed esser spiegato fisicamente, e tutto dev'essere considerato ed interpretato metafisicamente" (Introduzione alla filosofai, trad. de L. Gentilini, 1911, pag. 140).

(31) "Nous avons besoin de savoir où nous nous allons ou tout au moins de savoir que nous allons quelque part" (Émile Durkheim La morale en Allemagne, pag. 141).

(32) "Il est nécessaire que, non seulement de loin en loin, mais à chaque instant de sa vie, l'individu puisse se rendre compte que ce qu'il fait va vers un but. Pour que son existence ne lui paraisse pas vaine, il faut qu'il la voie d'une façon constante servir à une fin qui le touche immédiatement" (Émile Durkherm - Le suicide pg. 429).

(33) "La source du mouvement est dans le désirable et l'intelligible” (ArIstote, 2, Anal. II s. f.; Métaphysique, XII, 1072).

(34) Pensées de Pascall - texte de l'édition Brunschvicg, Garbier, 1925 — cap. "Misére de l'homme sans Dieu”, n." 73, pag. 86).

(35) "Summum bonum si ignoratur, vivendi rationem ignorari necesse est. Ex quo tantum error consequitur, ut quem in portum se recipiant scire non possint. Cognitis autem rerum finibus, cum intelligatur quid sit et bonorum extremum et malorum inventa vitae est conformatioque officiorum" (Cicero - De finibus, V).

(36) "L’obligation de faire son devoir uniquement par devoir, 
en vue du devoir seul, est le paradoxe de Kant" (Renouvier - Science et morale, Tom. I, pag. 124, 1. ${ }^{a}$ edic.).

(37) "Ce sera donc le concept de devoir, qui nous conduira à des fins et fondera sur des principes moraux les maximes à suivre relatives aus fins que nous devons nous proposer" (EMMANuel KanT - Eléments métaphysiques de la doctrine de la vertu - trad. de J. Barni, 1855, pags. 16/17).

(38) "Le concept du bien et du mal ne peut être déterminé avant la loi morale mais seulement après cette loi et par elle" (KANT - Critique de la raison pratique - trad. Picavet, pag. 127).

(39) "Agis suivant une maxime dont chacun puisse se proposer la fin suivant une loi générale" (KANT - Eléments métaphysiques de la vertu, trad. de Barni, edic. cit., pag. 38).

(40) "La philosophie nous apparait ici dans une fâcheuse situation, nous dit Kant dans les Fondements de la métaphysique des moeurs; cherchant un point d'appui solide, elle ne peut ni trouver dans le ciel où se suspendre, ni prendre pied sur terre" - trad. de H. Lachelier, 2.a edic. da op. cit., pag. 61).

(41) "L'aveu est flagrant, Kant sort de son rationalisme, pour entrer dans les formes religieuses de la pensée" (F. Sartiaux - Morale Kantienne et Morale Humaine, 1917, pag. 86).

(42) "J'ai interrogé la terre, et elle m'a dit: "Ce n'est pas moi". Et tout ce qu'elle m'a fait porte même aveu. J'ai interrogé la mer et les abîmes, et les êtres animés qui glissent sous les eaux, et ils ont répondu: "Nous ne sommes pas ton Dieu; cherche au dessus de nous J'ai interrogé l'air que je respire, et l'air avec ses habitants m'a dit de toutes pants: "Anaximénes se trompe; je ne suis pas Dieu. J'interrogue le ciel, le soleil, la lune, les étoiles, et ils me répondent: Nous ne sommes pas non plus le Dieu que tu cherches" Et je dis enfin à tous les objets qui se pressent aux portes de mes sens: "Parlez moi de mon Dieu, puisque vous n'êtes pas lui; dites moi de lui quelque chose" Et ils me crient d'une voix éclatante: "C'est lui qui nous a faits" (Les confessions de Sant Augustin - trad. de L. Moreau, Flammarion, Liv. X, VI, pag. 243).

(43) "On nous apprend à reconnaitre Dieu dans la fleur e dans l'arbre, l'on nous montre les étoiles, pour trouver dans leur nombre incommensurable et dans les lois de leus mouvement le plus sublime exemple de la toute puissance de l'Etre Suprême. Mais autant l'esprit s'élève au-dessus de la matiére, autant l'ordre et la lmajesté du monde intellectuel s'élèvent au-dessus du monde physique: la marche des. idées morales dans le temps est plus merveilleuse encore que le mouvement des corps célestes dans l'espace.

Celles-là ne procèdent point comme ces derniers, sans rencontrer d'obstacles; elles se heurtent à chaque pas contre la résistance que 
leur opposent l'obstination et l'ignorance des hommes, et toutes les mauvaises passions du coeur humain. Si malgré tout, ces idées se réalisent au milieu du conflit de toutes ces forces opposées, si le système planétaire du monde moral se meut avec le même ordre et la même harmonie que le système planétaire céleste, ily a là une manifestation de la divine providence plus éclatante que dans toute la nature extériure" (R. von IHERING - L'Esprit du droit romain dans le diverses phases de son développement - trad. de $\mathrm{O}$ de Meulenaere, $3 .^{a}$ edic., tom. I, pg. $\left.62, \S 5 .^{\circ}\right)$.

(44) Herbert Spencer - Les premiers principes, edic. cit., pag. 137).

(45) Maurice Blondel - Le probléme de la philosophie catholique, in Cahiers de la nouvelle journée, pag. 36).

(46) “A filosofia do direito é, como já vimos, ciência filosófica enquanto reune o direito á ordem universal. Mas o universal é estudado pela filosofia. Assim, a filosofia do direito deverá recorrer inevitavelmente aos primeiros principios que a filosofia geral estabelece" (Icilio Vanni - Lições de Filosofia do Direito, trad. de Octavio Paranaguá, 1916, pags. 11/12).

(47) Aristote - La politique, trad. de Thurot, revista por Bastien, Garnier, $\S 9 .^{\circ}$, pag. 5).

(48) "L'homme est né libre, et partout il est dans les fers"

Comment ce changement s'est-il fait? Je l'ignore.

Cependant ce droit ne vient point de la nature; il est donc fondé sur des conventions. Il s'agit de savoir quelles sont ces conventions". (Jean JacQues Rosseau - Du contrat social, liv. I, cap. I, Carnier, pag. 240).

(49) Auguste Comte - Plan de travaux scientifiques nécessaires pour réorganiser la société, 1822, pag. 78).

(50) "Si mon mari n'est pas un saint, qui esti-ce qui le sera?"

Thérése Rosseau, apud Jacques Maritain - Trois réformateurs: Luther, Descartes, Rousseau, $12 .^{\circ}$ milheiro, pag. 131).

(51) "L'homme, dans l'état de nature, aurait plutôt la faculté de connaître qu'il n'aurait des connaissances" (Montesquieu - De l'esprit des lois, Liv. I, cap. II, Flammarion, pag. 10).

(52) “Une aussi éminente intelligence, par suite même d'un avancemen $\iota$ trop prononcé, a néanmoins exercé sur son siècle une action immédiate bien inférieure à celle d'un simple sophiste, tel que Rosseau, dont l'etat intellectuel, beaucoup plus conforme à la disposition générale de ses contemporains, lui a permis de se constituer spontanément, avec tant de succès, l'organe naturel du mouvement 
purement révolutionaire qui devait caractériser cette époque" (Cours de philosophie positive, 47.' lic., tom. IV, pg. 132, edicc. de 1908).

53) “Or, le citoyen n'est pas juge du péril auquel la loi veut qu'il s'expose; et quand le principe lui a dit: “Il expédient à l'Etat que tu meures" - il doit mourir, puisque ce n'est qu'à cette condition qu'il a vécu en sûreté jusqu'alors, et que sa vie n'est plus seulement un bienfait de la nature, mais un don conditionnel del l'Etat" ( $D u$ contrat social, Liv. II, cap. V. pag. 261, edic. cit.).

(54) Essai théorique de droit naturel basé sur les faits, - TAPAReli D'Azeglio, 2. edic., 1875, tom. I, liv. II, cap. II.

(55) Sir Paul Vinogradoff, em sua obra "Principes historiques $d u$ droit, fala-nos das investigações robsonianas feitas no seculo XVIII, partindo do pressuposto do isolamento do homem.

(56) Philosophie de l'impérialisme et science du droit, 1932, n. ${ }^{\circ} 88$, pag. 244.

(57) Leslie Stephen - The English Utilitarians, II, pag. 315).

(58) Sir Paul Vinogradoff, -- Principes historiques du droit,

(59) "D'ailleurs, cette déclaration renferme un extrait ou une essence des erreurs promulgués par les premiers écrivains du siècle. S'il fallait restituer à chacun ce qui lui appartient, on verrait dans cette compilation les membres épars de Mably, de Rousseau, de Raynal, de Condorcet, de Diderot, de Price, de Priestley et de beaucoup d'autres. Mais ces faux principes, sanctionnés par l'assemblée nationale, ont un caractère de solennité qui leur manque dans ces écrivains". (Oellvres de Jérémie Bentham, Bruxelles, 1840, 3." edc., tom. I - "sophismes anarchiques", - pag. 506).

(60) Diz Sir Paul Vinogradoff: "En économie politique, l'influence de la pensée rationaliste fut plus profonde et produisit de plus grands résultats". (Principes historiques du droit - trad. de Duez e Longrais, 1924, pag. 121).

(61) "Ainsi, au XVIIIe. siècle, l'irritation causée par une féodalité surannée contribua puissament à produire le rationalisme, et plus particulièrement la politique et le droit rationalistes. D'autre part, la réaction contre l'idée que l'Etat et le Droit peuvent être délibérément changés, suivant des considérations de raison pure, se réfléchit dans le monde de la pensée, par une vénération nouvelle des éléments irrationels, inconscients, etc." (SIr Paulo VinogradofF - op. cit., edic. cit., pag. 137).

(62) W. Roscher - Geschichte der National - Oekonomie in Deutschland, München, 1874, pag. 500).

(63) Fichte - Reden an die Deutsche Nation, Berlim, 1808 reimpresso em Fichte's Saemmtliche Werke, tom. VII, pag. 257, edic. 1846). 
(64) Adam Mueller - Die Elemente der Staatskunst, apud Roscher - Grundlagen der Nationalökonomie, § 12).

(65) Geschichte der Deutschen Rechtswissenschaft, 3." parte, pag. 101.

(66) "Il (droit romain) est un droit héréditaire pour les peuples aussi bien que pour les individus; pour ceux-là comme pour ceux ci existe la vacance d'hérédité, cet intervalle qui s'écoule jusquà ce que l'heritier appelé ait accepté" (L'Esprit du droit romain, trad. cit., tom. I, pag. 13).

(67) Das Wesen den menschlichen Verbände, pag. 22). 127).

(68) “Les régles de la méthode sociologique, edic. 1895, pag.

(69) Synthetische Gedanken, pags. 57/5.8). BonNecase - Introduction d̀ l'étude du droit. - 1931, n. ${ }^{\circ} 182$, pag. 282).

(70) KaRL BrinkmanN - "Gesellschaftslehre" — apud WILHELM SAUER - Filosofia juridica y social, edic. 1933, trad. de Luis L. Lacambra, § 8, II, 1.*, pag. 37).

(71) “La réalité de la conscience sociale nous échappe: nous ne trouvons devant nous que des consciences individuelles" Alfred Fouillée - La science sociale contemporaine, pag. 241; "Concevoir la societé comme existant en dehors des individus, c'est de la pure métaphysique" - A. FoullléE, - Le mouvement positiviste et la conception sociologique du monde, pag. 248).

(72) "Le sociologisme métaphysique a revêtu, en effet, deux formes, respectivement concrétisées par les doctrines d'Auguste Comte et de Durkheim. Le premier, parti d'une affirmation métaphysique, a abouti à une doctrine d'allure pseudo-religieuse; le second, tout en reniant la métaphysique, n'en a pas moins donné son adhésion implicite à cette discipline, car tout le système de Durkheim repose sur une proposition non verifiée expérimentalement, donc à caractière métaphysique" (Julien Bonnecase - Philosophie de l'impérialisme et science du droit, 1932, pag. 214). Conf. Geny - Science et technique - tom. II, n. $0^{\circ} 81$ ).

(73) Garrigou - Lagrange - Le sens commun, 2.* edic., pag. $322 / 323)$.

(74) Tristão de Athayde - Politica - edic. 1932, pag. 17).

(75) "Hace unos diez o quince años - (los límites de los momentos ideológicos son siempre fluctuantes y difumados) - pudo celebrar-se ufanamente la plena restauración de la Filosofia del Derecho. Casi durante medio siglo, el pensamiento jurídico - de modo parejo a las otras ciencias - fué desmochado por el positivismo de todo cuanto implicara preocupaciones auténticamente filosóficas, y reducido a una mera tarea de interpretación empírica y al estudio de los hechos sociales que circunscriben y determinam el fenómeno juridico. 
Pero ya a fines del siglo XIX penetran en el ámbito de la Ciencia jurídica corrientes renovadoras que proceden del renacimiento filosófico general que se había iniciado hacia 1870. Podemos decir que, en general, este despertar de la preocupación filosófica acerca del Derecho se efectúa en gran parte merced a la tarea de autores, que estaban influídos capitalmente por las corrientes del idealismo neocriticista" Luis R. Siches - Prólogo á Filosofia del Derecho del Prof. Georgio del Vecchio, trad. do mesmo Siches, Barcelona, 1929, tom. I, pags. III/IV).

“(La sociologie juridique) atteste moins une conviction scientifique qu'une impuissance découragée à se hausser au niveau des principes" (F. GENy - Science et technique, tom. II, n. ${ }^{\circ}$ 81, p. 60).

(76) Conf. Emmanuel Levy -- Le Droit repose sur les croyances, 1909.

(77) "Pour obtenir, de façon décisive, avec une plénitude assurée et une fermeté convaincante, le principe des normes directrices de l'activité morale ou juridique, il faut avoir pris parti sur la conception générale de l'Univers, sur l'essence et la nature de l'homme, sur le mystère de son origine et de son existence en ce monde, sur l'énigme de sa destinée. Qu'importe que pareilles recherches menacent de nous entrainer à l'abîme? Le risque vaut d'être couru, si nous ne pouvons autrement acquérir la confiance indispensable à l'action! (Françors Geny - Science et technique, edic. cit., tom. II, n.' 162, p. 354$)$.

(78) "O individuo, que empreende uma excursão pelos vastos domínios da ciência jurídica, tem obrigação de premunir-se com certas idéias fundamentais, que serão os seus guias através dessas regiões tão trilhadas e, a-pesar-disso, ainda tão desconhecidas. Sem esse preparo prévio, arrisca-se a mostrar-se como um espírito lamentavelmente vacilante e desconjuntado, que pode ser evolucionista em ciências naturais, metafísico em direito e fetichista em religião" (Ciovis Bevilaqua - Linhas e perfis juridicos, 1930, pag. 12).

(79) "Mais il ne faut pas oublier que le travail normal de l'intelligence est loin d'être un travail désintéressé. Nous ne visons pas, en général, à connaître pour connaître, mais à connaître pour un parti à prendre, pour un profit à retirer, enfin, pour un intérêt à satisfaire. Nous cherchons jusqu'à quel point l'objet à connaître est ceci ou cela, dans quel genre connu il rentre, quelle espèce d'action, de démarche ou d'attitude il devrait nous suggérer" (HENri Berson - Introduction à la métaphysique, in Revue de métaphysique et de morale, 1903, tom. XI, pag. 16).

(80) Luis Recasens Siches - Direcciones contemporáneas del pensamiento juridico (La filosofia del Derecho en el siglo XX) (Coleção Labor. $n .^{\circ} 198$, pags. 11/15). 
(81) V. Ciathrein - Moral philosophie, 4 A, 1904, tom. I, Einleitung, II, 5, pags. 10/15).

(82) "En d'autres termes, il faut qu'ils aperçoivent l'idée d'un but de leur existence, puis, pour arriver à ce but, l'idée d'un moyen" (J. Oudor - Conscience et science du devoir, edic. 1855, tom. I, pag. 41).

(83) Cuicumque est aliquid naturale, opportet etiam esse naturale ide sine quod illud haberi non potest. Est autem homini naturale quod sit animal sociale; quod ex hoc ostenditur quod unus homo solus non sufficit ad omnis quae sunt humanae vitae necessaria. Es igitur sine quibus societas humana conservari non potest sunt homini naturaliter convenientia. Hujusmodi autem sunt: unicuique quod suum est conservare et ab injuria abstinere" (SÃo TOMAZ DE AQUINo - Summa contra Gentiles, I, III, cap. 129).

(84) Lex data, sive divinitus, sive humanitus, inclinatione respondet et eam perficit. Inest autem homini naturalis inclinatio ad ommnium hominum dilectionem" (São Tomaz de AQurno, Summa Contra Gentiles, III, 130).

(85) "Lex quaedam regula eș̣̂ et mensura actuum, secundum quam inducitur aliquis ad agendum vel ab agendo retrahitur ( $\mathrm{S}$. Thomaz). "Tandis qu'ici, la régle veut dire: fais ceci; et la mesure: dans telles limites". (C. MARTYNIAK — Le fondement objectif du droit d'aprés Saint Thomas d'Aquin, edc. de 1931, pag. 14).

(86) "Loi physique, loi sociale ou morale, toute loi est à leurs yeux un commandement. Il y a certain ordre de la nature, lequel se traduit par des lois: les faits obéiraient à ces lois pour se conformer à cet ordre.

"Mais si la loi physique tend à revêtir pour notre imagination la forme d'un commandement quand elle atteint une certaine généralité, réciproquement un impératif qui s'adresse à tout le monde se présente un peu à nous comme une loi de la nature. La loi prend au commandement ce qu'il a d'impérieux; le commandement reçoit de la loi ce qu'elle a d'inéluctable. Une infraction à l'ordre social revêt ainsi un caractère antinaturel: même si elle est fréquemment répétée, elle nous fait l'effet d'une exception qui serait à la société ce qu'un monstre est à la nature". Que sera-ce, si nous apercevons derriére l'impératif social un commandement religieux! (HENRI Bergson - Les deux sources de la morale et de la religion, 14 edic. pag. 5).

(87) “Affirmer la finalité, ce n'est rien poser d'avance dans le réel, c'est simplément affirmer une orientation des faits, à la différence d'une poussée indéterminée et quelconque, dont la notion n'est même pas concevable, ne répondant à rien qui se puisse définir" (Sertillanges, Dieu ou rien, edic. cit. tom. I, pag. 28). 
(88) “Qu'il y ait un ensemble de notions répondant à l'idée d'une justice une et impersonelle, absolue et universelle, ce n'est pas sérieusement contesté. Socrate l'affirmait contre les sophistes, qui professaient la politique de la forme ou la morale du plaisir; c'est l'argument du Georgias et le fond des réponses aux Discours de Gadiclès; c'est le principe philosophique des "lois non écrites", fondement de la théorie de la justice exposée dans l'Entretien avec Hipias. L'obéissance aux lois de la cité n'est que le devoir strict du citoyen et une des formes du patrotisme; la véritable justice est plus haut, elle est au-dessus de la loi, comme la vérité est au-dessus de la coutume; elle consiste dans l'obéissance aux lois supérieures, fondées par la volonté des dieux, qui commandent à tous les hommes, chez tous les peuples, dans tous les temps: les lois non écrites. L'idée, comme le mot, sont depuis restés. Antigone, dans Sophocle, accusée d'avoir violé les décrets de Créon, en appelle aux lois non écrites: "Je n'ai pas cru que tes ordres eussent assez de force pour que les lois non écrites mais impérissables, émanées des dieux, dussent fléchir devant un mortel. C'est ne pas d'aujourd'hui, ce n'est pas d'hier qu'elles existent: elles sont éternelles, et personne ne sait où elles ont pris naissance". Plusieurs siècles après, Plutarque disait à son tour: "Qui esti-ce qui commandera au prince? La loi. Non une de ces lois qu'on écrit dans les livres ou qu'on grave sur les bois, mais la loi innée, la loi qui vit au fond de la conscience de l'homme: la raison".

A Rome, mêmes aspirations vers un idéal de justice et d'équité. Au moment où disparaissait le vieux Droit romain, formaliste et rigoureux, aux épicuriens, qui présentaient l'utilité et la convenance comme seuls principes générateurs du Droit, Ciceron opposait la distinction de l'équité naturelle et de l'équité légale: aequitas naturalis, aequitas constituta; il devenait par là le précurseur de la grande époque de la jurisprudence romaine. Si la loi est changeante, le Droit est éternel, car il a son fondement non dans l'opinion, mais dans la nature: "Neque opinione, sed natura constitutum esse jus.. Non ergo a proetoris edicto ut plerique nunc, neque a XII tabulis, ut superiores, des penitus ex intima philosophia hauriendam juris disciplinam putas" Qui ne connaît ces paroles du défenseur de Milon: "Est igitur haec, judices, non scripta sed nata lex; quam non didicimus, hausimus, expressimus; ad quam non docti, sed facti, non instituti, sed imbuti sumus" Et ce fragment de la République: "Est quidem vera lex, recta ratio, naturae congruens, diffusa inommes, constans, sempterna. - Huic legi nec abrogari fac est neque derogari licet. neque est quoerendus explanator aut interpres ejus alius; nec erit alia Romae alia Athenis, alia nunc, alia posthac; sed et omnes gentes et omni tempore una lex et sempiterna et immutabilis conti- 
nebit. Cui qui non parebit ipse se fugiet, ac naturam hominis aspernatus hoc ipso luet maximas poenas, etiamsi caetera supplicia, quae putantur, effugerit. Où est cette loi? Elle est exposée aux yeux de chacun dans le grand livre du monde, sur les Tables de la Nature, répond Quintillien: "In publico mundi, in naturalibus tabulis" Quelles superbes évocations! Ce sont elles qui inspirent les jurisconsultes du grand siècle. Leurs formules sont plus brèves et moins imagées, la notion exprimée n'en est que plus précise. Le Droit, pour Paul, c'est la naturalis ratio, quasi lex quaedam tacita; il ajoute ailleurs: "Quod semper aequm et bonum est jus dicitur, ut est jus naturale"

"La tradition se perpétuera, jamais interrompue, ravivée d'âge en âge au contraire; l'appel au droit sera le cri des opprimés de tous les temps, et le té moignage incessamment renouvelé des hommes qui marquent les étapes dans l'histoire des progrès de la pensée humaine. Les pères de l'Eglise au temps de la persécution, saint Thomas d'Aquin, lorsque la théocratie fut toute-puissante, les philosophes, depuis que le droit naturel s'est séparé de la morale pour constituer un corps distinct de doctrine, Bodin, Grotius, Leibnitz, Locke, proclameront l'existence d'un droit ayant sa source en lui-même, supérieur à toutes puissances. Montesquieu ne fera que résumer la pensée traditionelle et commune en disant: "Les êtres particuliers et intelligens peuvent avoir les lois qu'ils ont faites; mais ils en ont aussi qu'ils n'ont pas faites. Avant qu'il y eût des lois faites, il y avait des rapports de justice. Dire qu'il n'y a rien de juste ni d'injuste que ce qu'ordonnent ou défendent les lois positives, c'est dire qu'avant qu'on eût tracé de cercle, tous les rayons n'étaient pas égaux"

“La notion d'un droit naturel se présente donc sous l'autorité d'un sentiment séculaire et universel. Cependant elle est aujourd'hui contestée; le positivisme contemporain rejette le mot et conteste l'idée qu'on y attache communément; M. Courcelle-Seneuil s'est constitué tout particulièrement, de nos jours, l'adversaire de "ce concept", comme il l'appelle; à l'egard de ceux qui l'admettent, les "intuitifs" comme il les nomme, par opposition aux "savants modernes", il a l'attitude du croyant à l'égard les hérétiques; au ton âpre dont il les traite, on soupçonne qu'il les supprimerait volontiers, s'il pouvait" (Charles Beudan - Le droit individuel et l'État, 2." edic. 1891, pags. 29 e segs.).

(89) “Dès l'aube de son bistoire, la Chine a cru à l'existence d'un ordre naturel qui embrasse tioutes les parties de l'univers et les ajuste l'une à l'autre dans un fonctionnement harmonieux. Cet ordre n'a pas été créé. Il existe, et il est á luimême sa raison d'être. L'humanité en fait partie et doit s'y conformer. Comme les éléments de cet ordre naturel sont interdépendants, tout ce qui affecte l'un réagit 
sur les autres. Un trouble sur la terre provoquera un désordre dans le ciel. Pour remédier au mal que se trouble engendre, il est nécessaire et suffisant de retablir lordre là où il a été originairement altéré. Il est aisé de voir les conséquences qu'entraine, dans le domaine du gouvernement, de l'administration et de la justice, une pareille conception. Signalons les plus importantes, l'ordre naturel exclut la prédominance de lois positives présentes comme le fruit de l'experience et de la sagesse humaines; la loi positive doit se borner à traduire en formules écrites l'ordre naturel. Si la traduction est exacte, la loi est bonne et s'impose, si la traduction est mauvaise, le prince ou le gouvernement, en l'édictant, ont mal interprété l'ordre naturel, la loi écrite ne vaut pas. Le Chinois considérera comme obligatoire une régle positive promulguée dans des conditions de régularité constitutionelle douteuses lorsqu'il la tient pour conforme aux "décrets d'en haut"; mais il se dispensera de l'observer, fût-elle émanée du prince le plus légitime, s'il la croit en désaccord avec l'ordre naturel.

L'dée ne lui viendra pas qu'un même acte puisse être permis ou interdit, bon ou mauvais, juste ou injuste, indépendamment de sa qualité morale intrinsèque, seulement parce que le dépositaire du pouvoir en aura ainsi décidé.

M. Leang K'i-Tch'Ao a tenté d'exposer les vicissitudes d'une Ecole de penseurs qui a joué en Chine un rôle considérable, qui n'a pas réussi à faire prévaloir ses doctrines, mais dont on discerne les traces jusque dans la pensée contemporaine, l'Ecoles des Légistes." (Prefacio de G. Padoux á obra de Leang K'I-Tch'Ao: La conception de la loi et les théories des légistes à la veille des T'Sin, trad. de Escarra e Robert Germain, 1926).

(90) “Les commandements du droit sont érigés en commandements de Dieu, soit isolément, lorsqu'ils sont d'une importance et d'une gravité morales spéciales, soit dans leur ensemble. Ni l'intention, ni le calcul, ni une fraude pieuse n'en sont la cause; mais bien le sentiment de la nature morale du droit, qui, comme voix de Dieu, est subjectivement perceptible pour la nature religieusement douée, et qui, objectivement, impose ses inspirations et ses vues comme des révélations divines" (Rudolf von IHERING - L'Esprit du droit romain — edic. e irad. cits, tom. I, p. 267).

(91) "Chez les Grecs et chez les Romains, comme chez les Hindous, la loi fut d'abord une partie de la religion.

“. droit et religion ne faisaient qu'un" (Fustel de Coulanges -La cité antique, 17." edic., liv. III, cap. XI, pags. 218/219).

(92) “I $n$ 'y a là qu'une différence, quantitative plutôt que qualitative, d'ailleurs contingente et variable avec la civilisation, au 
regard de la morale et de la religion, qui, si elles élargissent le cercle des devoirs, n'en comprennent pas moins beaucoup de ceux rentrant également dans la sphere du droit" (Françors Geny - Science et technique, edic. cit, tom. I, pag. 49/50).

(93) "Et le droit ne doit pas seulement viser à un strict minimum de la vie rertueuse indispensable pour l'existence de la societé, un minimum qu'il ne devrait' jamais dépasser, mais le niveau moral des lois doit varier avec celui des sujets tout en le dépassant un peu. pour hausser la moralité sociale et en obtenir le maximum concrètement possible" (C. Marty Nia - Le fondement objectif du Droit d'après Saint Thomas d'Aquin, edic. cit., pag. 168).

(34) “ .sich selbst heilig machen” (MAx Scheler - Der Formalismus in der Ethik und die materielle Wertethik, 2." edic. 1816, pag. 31).

“Ainsi s'affirme la différence de la règle de droit et de la règle morale. La première est intérieure à la société; elle en émane: elle s'arrête au bien commum. Son but idéal est d'établir entre les éléments divers: économiques, politiques, moraux, culturels, un ordre qui donnant à la société sa forme statique, assure le respect des droits de chacun et la coexistence pacifique de tous, et qui, dans sa fonction dynamique, aide à faire naitre et à répartir toutes les "valeurs" de la vie humaine, depuis la sécurité individuelle et la prospérité métérielle jusqu'aux valeurs qui conditionnent l'enrichissement spirituel des âmes.

“La règle morale, elle, est édictée par la raison ou par une autorité qui peut commander à la conscience de l'homme, créature intelligente et libre. Au nom de notre nature, dont la raison et la conscience sont les interpretes, et au nom Dieu, elle nous donne la règle de conduite conforme à notre ideal de vie humaine. Son but est de nous mener à notre perfection d'êtres raisonnables, c'est-à-dire d'êtres qui en tous leurs actes accomplissent fidèlement ce que la raison leur intime au nom de leur idéal naturel" (J. T. DELos, professor na Faculdade de Direito de Lille - Le probléme des rapports du droit et de la morale, in Archives de Philosophie du droit et de Sociologie juridique, Anno III, nos 1/2, pag. 90).

95) GeORge RIPERT - La règle morale dans les obligations civiles, 2. edic., n. 7 , pag. 13 ).

(96) Tomaz de AQuino, Summa Theologica, I. Iae, q. 58, art. 5 ad primum.

"Oportet quod omnes actiones humanae propter finem sint" (SÃo Thomaz - Summa theologica, I", IIae, q. 1, art. I).

(97) Filosofia do Direito - preleções do Exmo. Sr. Dr. JoÃo Arruda - taquigrafadas por Manuel Alves de Souza, sem responsabilidade da ilustre cadeira, 1915, 2.' edic., pag. 181). 
(98) “Or la société n'est que bien rarement considérée par les spécialistes comme la cause déterminante des faits dont elle est le théâtre. Même le principe de l'interdépendance des faits sociaux, bien qu'lassez facilement admis dans la théorie, est loin d'être efficacement mis en pratique. Aussi, bien que les sciences sociales partículières tendent à s'orienter dans un sens sociologique, cette orientation reste encore indécise. Travailler à la préciser, à l'accentuer, à la rendre plus consciente, telle est, pense M. Durkheim, la tâche actuelle du sociologue.

Et ainsi apparaît finalement le caractère vrai de la sociologie, telle que la conçoit M. Durrkheim:' elle n'est pas une sciente, mais une méthode" (Simon Deploige - Le conflit de la morale et de la sociologie, 4." edic., cap. II, pag. 85).

(99) "Luis R. Siches - Direcciones contemporáneas del pensamiento juridico, edic. cit., pag. 20.

(100) Rudolf Stammler - Rechtsphilosophie Abhandlungen und Vortäge, edic. 1925.

(101) LÉon Duguit - Traité de Droit constitutionnel, 3." edic. tom. I, pag. 70 .

(102) Rudolf von Ihering - El fin en el dereccho - trad. de Leonardo Rodrigues, $n .^{\circ} 180$, pag. 274).

(103) Archives de Philcsophie du droit et sociologie juridique - 1933 n. 1/2 - que traz á pag. 68 um artigo de Giagomo PertiCONE - L'action juridique.

(104) Rudolf Stammler - Wirtschaft und Recht nach der materialistichen Geschichtsauffassung, 1906, pags. 335/474).

(105) (LÉon Duguit - Traité de Droit Constitutionnel, edic. cit., vol. I, pag. 82).

(106) Rudolf Stammler - op. cit., 2." edic., 1906, § 22, pags. $112 / 121)$.

(107) Luis R. Siches - Filosofia del derecho por el prof. Giorgio del Vecchio, trad. de Siches - 1929, tom. I, pag. 129).

(108): A. D. Sertillanges - Dieu ou rien, $7 .^{\circ}$ milheiro, tom. II, pags. $103 / 4)$.

(109) Georges Ripert - La règle morale dans les obligations civiles - 2." edic., n.' 18, pag. 31).

(110) LÉon Duguit - op. cit., edic. cit., $\S 8$, tom. I, pag. 99).

(111) Rudolf Stammler - op. cit., edic. cit., II, pag. 286).

(112) Filosofia del derecho - por el prof. Giorgio del Vecchio, trad. de Luis R. Siches, tom. I, pag. 441).

(113) Science et technique en droit privé positif, 1922, tom. I, pag. 74).

(114) L'homme incapable de réfléchir n'est sensible qu'aux souffrances réelles; mais, pour l'homme qui pense, au torment réel 
vient s'ajouter une perplexité théorique: il se demande pourquoi un monde et une vie, faits après tout pour qu'on y isoit hereux, répondent si mal à leur fin? (SchopenHAUER - Le monde comme volonté et comme représentation, tom. III, pag. 446).

(115) "Natura invite vult mori, nec premi, nec superari, nec subesse, nec spont subjugari - (Imitação de Christo, liv. III, pag. 56).

(116) Gabriel TaRde - Les transformations du droit - 6." edic., cap. IV, pag. 128).

(117) Cours de Droit Naturel ou de Philosophie du Droit, edic. 7.", tom. I, pags. 207/208).

(118) "Persona comparatur ad communitatem sicut pars ad totum" (SÃo Tomaz de AQuino, Summa Theologica, II.", IIae, q. 61, art. 1).

(119) "qui quaerit bonnum commune, quaerit proprium, quia bonum proprium non potest esse sine communi et bona dispositio partis est in respectu ad totum" (SÃo Tomaz de AQuino, Summa Theologica, $\mathrm{II}^{\mathrm{a}}$., Hae, q. 47, art. 10, ad secundam).

(120) Archives de Philosophie du Droit et de Sociologie juridique - 1933 Le problème de l'obligation chez Duguit et chez Kelsen - por Georges Davy, pag. 7 e segs.).

(121). Georges Gunvitch - Le temps présent et l'idée du droit social-Avant-propos — pag. 7, edic. de 1931).

(122) Pe. Leonel da Franca - A Igreja e a crise social alocução proferida na sessão inaugural da Sociedade Juridica de Sto. Ivo, em 26 de Setembro de 1928, no Palacio de Justiça da Capital Federal, in Jornal do Comércio de 14-X-928).

(123) MaXime Leroy - na revista "Europe" de 15-IV-923, pag. 325).

(124) Rudolf von Ihering - El fin en el derecho - trad. de Leonardo Rodrigues - pag. 8).

(125) Edmond Picard - Le droit Pur - in Bibliothèque de Philosophie scientifique — 1908, § 7, pags. 13/14).

(126) "Aqui se nos depara uma das variações para não dizermos contradições, em que flutúa o pensamento de Ihering, e que seus críticos com indiscutiveis fundamentos apontam na obra filosófica do ilustre mestre. A principio afirma Ihering que, ao lado do egoismo, há um outro motor da vontade, denominado: a abgnegação, o desinterêsse, o espírito de sacrifício, o amor, o devotamento, a compaixão, a benevolência, expressōes todas sinônimas. $O$ individuo tem o sentimento da destinação moral de sua existencia -- reconbece que é solidário com toda a humanidade. Afinal, reconhece que o egoismo é o fato fundamental de nosso dinamismo psiquico, o motivo ao qual todos os outros se reduzem" (Estudos de Filosofia do Direitio, Pedro Lessa, 2.' edic., pag. 418). 
(127) “E' realmente como diz o Sr. Dr. Lessa um trecho bas T tante confuso da obra de Ihering. E' neste ponto que Ihering confessa que não é um psicólogo, mas sim um jurista" (Filosofia do Direito - Preleções do prof. JoÃo ArRuda - sem responsabilidade da ilustrada cadeira - pelo aluno Manuel Alves de Souza - 2." edic., pag. 110).

(128) O. Gierix - Deutsches Privatrecht, 1895, tom. I $\S 15$, pag. 121, e Wilhelm Sauer - Filosofia juridica y Social, trad., de Lacambra, § 6, I, nota 14).

(129) “Sin formación filosófica profunda y influenciado por el utilitarismo inglés, especialmente por el de John Locke, vió, sin embargo, com genial intuición en la idéa de "fin" el elemento "creador" del Derecho, preparando así la dirección teleologica en el estudio del Derecho - en su doble orientación hacia la Sociologia y la Filosofia de la cultura - accentuando la mision prática del Derecho, que es servir de protección de los interesses vitales del hombre; pero no comprendió el fin en sel sentido de una idea para la formación del Derecho, sino en el sentido del historicismo, como lo devenido; en el sentido del positivismo, como hecho, y en el sentido del naturalismo, como causa psiquica" (Wilhelm SAuer - Filosofia juridica y social — trad. de Lacambra, 1933, § 6, II, pag. 19).

(130) “Adviétase empero, que a pesar de la pontecialidad filosófica de la labor de Ihering, y a pesar de contener en muchos aspectos elementos para la superación del historicismo, no logra eleviarse por encima del plano del empirismo, ni por ende hallar el ideal juridico, quedándose en la mera explicación de los fines concretos a que el Derecho ha servido efectivamente aqui y allí, antes y ahora". (LuIs R. Siches - adiciones á Filosofia del Derecho do prof. Giorgio. del Vecchio, 1930, tom. II, pag. 239).

(131) "Eso se enuncia como un gran descubrimiento, cuando non es realmente otra cosa que una adulteración y enervación de la doctrina panteísta evolutiva" (J. KoHLER - Filosofia del derecho $\boldsymbol{y}$ historia universal del derecho, trad. de Castillejo e Duarte, 1910, § 7, pag. 38$)$.

(132) Tristão de Athayde - Introdução ao Direito Moderno, 1933, pag. 288).

(133) Paul Vander Eycken - Méthode positive de l'interprétation juridique, 1907.

(134) Francois Geny - Science et technique en droit privé positif, 1922 , tom. II, n.' 76 , pags. $40 / 41$ ).

(135( vid. n.' 117).

(136) "In der gegenwärtigen (zweiten) Auflage mache ich zum Texte einen Nachtrag, den ich der Besprechung meines Werkes im Literarischen Handweiser, zunächst für das katholische Deutschland 
Münster, Jahrg. 23, nr. 2 durch W Hahoff, Kaplan in Häffe, verdanke, der mir auch persönlich mit manchen wertvollen Verweisungen auf die katholische ethische Literatur an die Hand gegangen ist. Derselbe weist mir durch Zitate aus Thomas ab Aquino nach, dass dieser grosse Geist das realistisch-praktische und gesellschaftlische Moment des Sittlichen ebenso wie das historiche bereits vollkommen richtig. erkannt hatte. Den Vorwurf der Unkenntnis, den er für mich daran knupft, kann ich nicht von mir ablehnen, aber mit ungleich schwererem Gewicht als mich trifft er die modernen Philosophen und protestantischen Theologen, die es versäumt haben, sich die grossartigen Gedanken dieses Mannes zunutze zu machen. Staunend frage ich mich, wie war es möglich, dass solche Wahrheiten, nachdem sie einmal ausgesprochen waren, bei unserer protestantischen Wissenschaft so gäzlich in Vergessenheit geraten konten? Welche Irrwege hätte sie sich ersparen könne, wenn sie dieselben beherzigt hätıe! Ich meinerseits hätte vielleicht mein ganzes Buch nicht geschrieben wenn ich sie gekannt hätte, denn die Grundgedanken, um die es mir zu tun war, finden sich schon bei jenem gewaltigen Denker in vollendeter Klarheit und prägnantester Fassung ausgesprochen. (RudolF von Ihering - Zweck im Recht, 4." edic. 1905, cap. IX, n. 161, nota 2, pag. 125). 